\title{
A Rural Medieval Settlement and Early Iron Age Funerary Remains at Hallhill, Dunbar, East Lothian
}

\author{
Stuart Mitchell \& Sue Anderson
}

with contributions by A Cox, R Ceron-Carrasco, D Hall, A Jackson \& C Smith

Scottish Archaeological Internet Report 50, 2011 www.sair.org.uk 
Published by the Society of Antiquaries of Scotland, www.socantscot.org.uk with Historic Scotland, www.historic-scotland.gov.uk

and the Council for British Archaeology, www.britarch.ac.uk

Editor Helen Bleck

Produced by Archétype Informatique SARL, www.archetype-it.com

ISBN: 978-1-908332-00-4

ISSN: $1773-3803$

Requests for permission to reproduce material from a $S A I R$ report should be sent to the Director of the Society of Antiquaries of Scotland, as well as to the author, illustrator, photographer or other copyright holder.

Copyright in any of the Scottish Archaeological Internet Reports series rests with the SAIR Consortium and the individual authors.

The maps are reproduced from Ordnance Survey material with the permission of Ordnance Survey on behalf of The Controller of Her Majesty's Stationery Office. (C) Crown copyright 2001. Any unauthorised reproduction infringes Crown copyright and may lead to prosecution or civil proceedings. Historic Scotland Licence No. GD 03032G, 2002.

The consent does not extend to copying for general distribution, advertising or promotional purposes, the creation of new collective works or resale. 


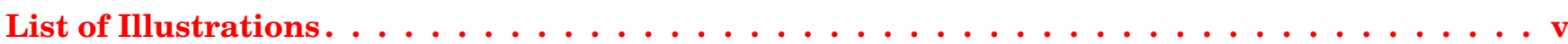

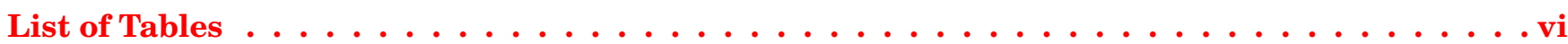

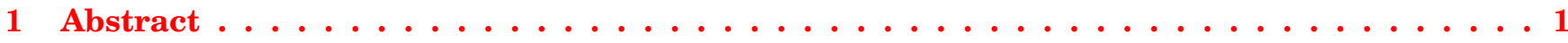

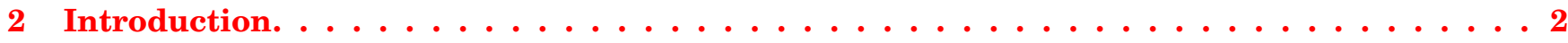

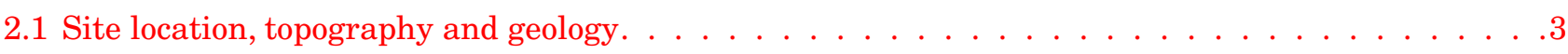

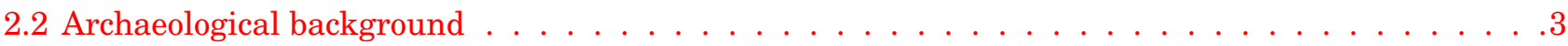

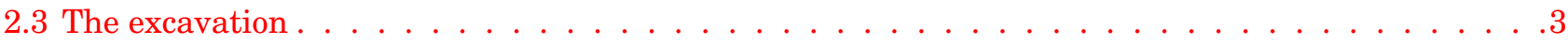

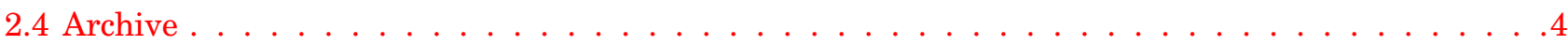

3 The Square Enclosure, Possible Grave and Associated Features (Trench 1) . . . . . . . . 5

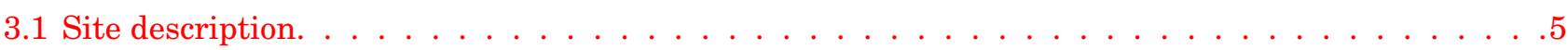

3.2 Human skeletal remains, by Sue Anderson . . . . . . . . . . . . . . . . . . . . . 6

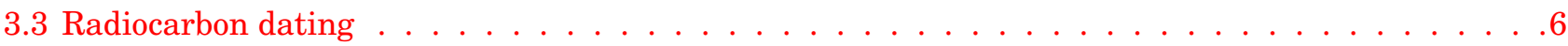

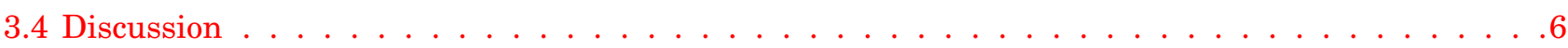

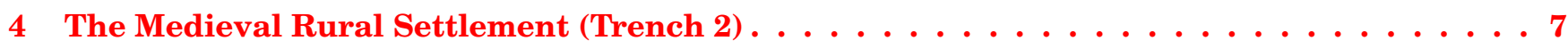

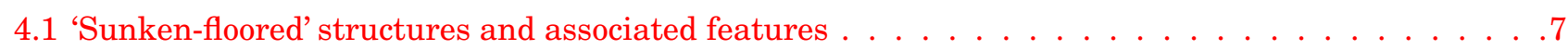

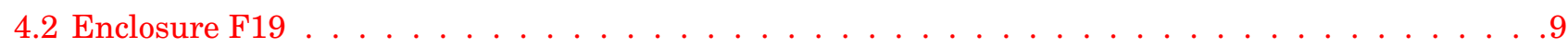

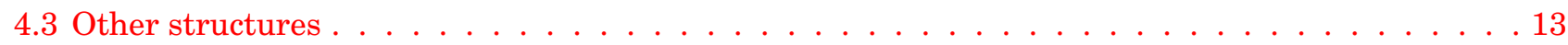

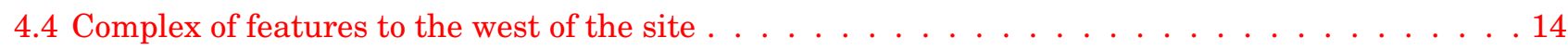

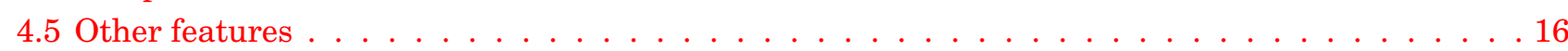

5 Artefactual and Environmental Evidence (Trench 2) . . . . . . . . . . . . . . 17

5.1 Medieval pottery, by Derek Hall . . . . . . . . . . . . . . . . . . . . . . . . . . 17

5.2 Copper alloy objects, by Adrian Cox . . . . . . . . . . . . . . . . . . . . . . . . . 20

5.3 Iron objects, by Adrian Cox . . . . . . . . . . . . . . . . . . . . . . . . 22

5.4 Glass, by Adrian Cox. . . . . . . . . . . . . . . . . . . . . . . . . 23

5.5 Coarse stone, by Adam Jackson . . . . . . . . . . . . . . . . . . . . . . . . 24

5.6 Animal bone, by Catherine Smith . . . . . . . . . . . . . . . . . . . . . . 26

5.7 Marine shell remains, by Ruby Ceron-Carrasco . . . . . . . . . . . . . . . . . . . . . . . . 29

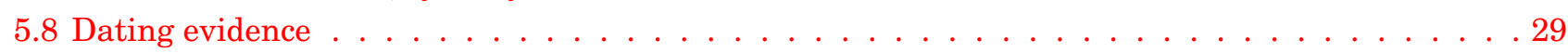

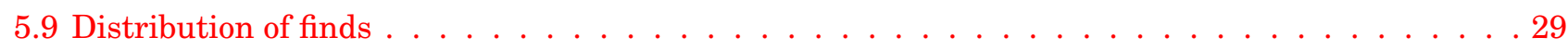

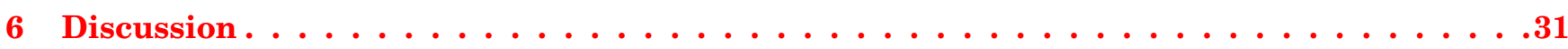

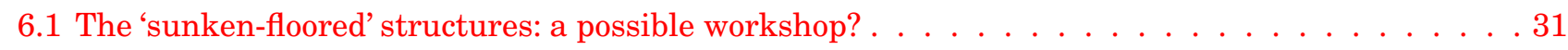

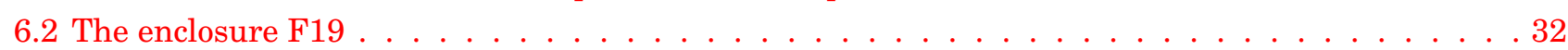

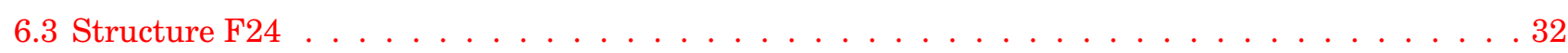

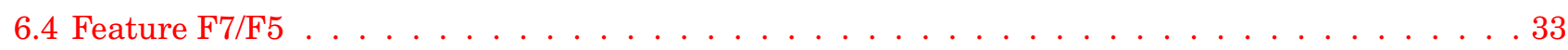




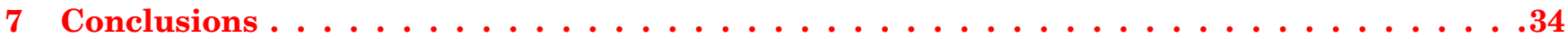

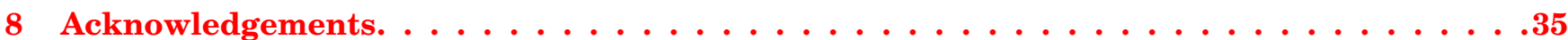

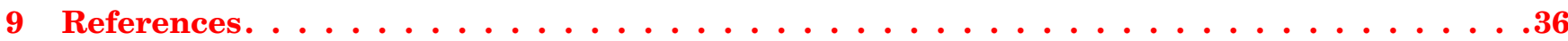




\section{LIST OF ILLUSTRATIONS}

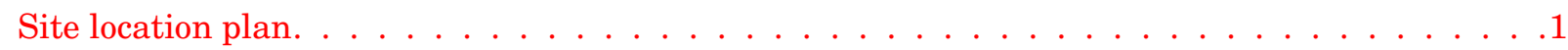

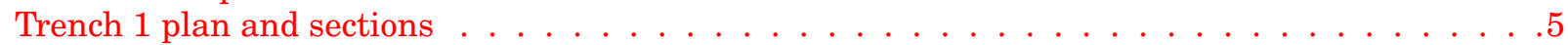

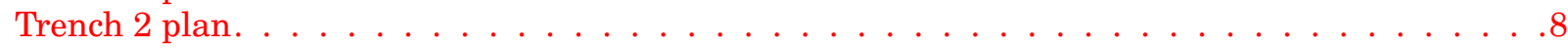

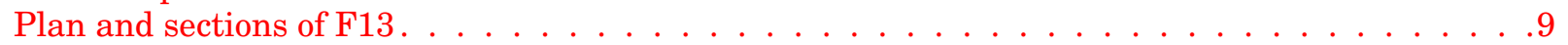

Pit 1313 half-sectioned with in situ stones in upper fill visible including pivot stone . . . . . . 10

Plan and sections of F14 . . . . . . . . . . . . . . . . . . . . . 10

South-facing view of F14 with pit $1426 \ldots \ldots \ldots \ldots$. . . . . . . . . . . . 11

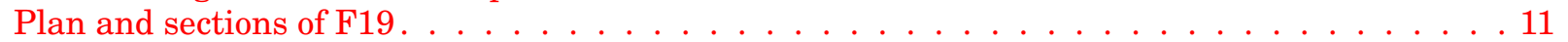

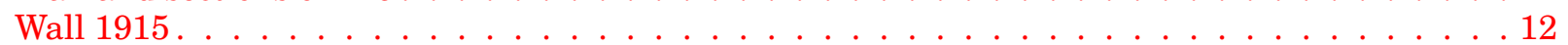

Plan and sections of $\mathrm{F} 22 / \mathrm{F} 24 \ldots \ldots \ldots \ldots$

North-facing surface view of $\mathrm{F} 24 \ldots \ldots \ldots \ldots$

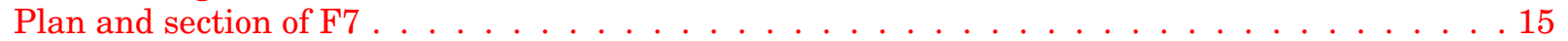

Medieval pottery . . . . . . . . . . . . . . . . . . . . . 18

Medieval pottery . . . . . . . . . . . . . . . . . . . . 19

Copper alloy finds . . . . . . . . . . . . . . . . . . . . . . 20

Iron finds . . . . . . . . . . . . . . . . . . . . . . . . . . 22

Window glass . . . . . . . . . . . . . . . . . . . . . . . 23

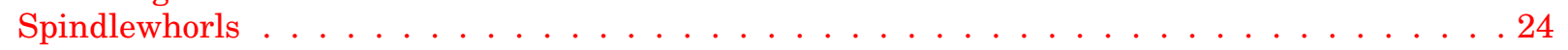

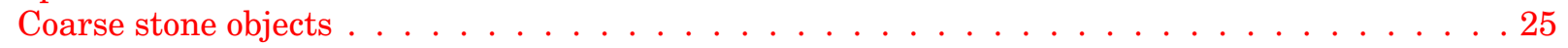




\section{LIST OF TABLES}

1

Total numbers of animal bone . . . . . . . . . . . . . . . . . . . . 26

Numbers and percentages of food-forming mammals at Hallhill Farm and

Castle Park, Dunbar . . . . . . . . . . . . . . . . . . . . . . . . . . . . 27

3

Wear stages of sheep/goat mandibles from Hallhill Farm . . . . . . . . . . . . . . . 27

Numbers and percentages of cattle and sheep/goat long bones, by age category . . . . . . . . 27

The marine shell remains . . . . . . . . . . . . . . . . . . . . . . . . . . 29 


\section{ABSTRACT}

An archaeological excavation at Hallhill, Dunbar, has revealed the remains of a rural medieval settlement. Few such sites have been identified in Scotland. Two irregular structures, an enclosure and other possible structures, as well as numerous pits and several gullies and ditches were identified. Large quantities of medieval pottery were recovered from the fills of many of the features, as well as animal bone, coarse stone and metal artefacts. Further to the north, a sub-square ditched enclosure was also found, although this could not be stratigraphically related to the medieval remains and is undated. Adjacent to it was a pit containing incomplete remains of a human skeleton which have been dated to the Late Bronze Age. The work was sponsored by George Wimpey East Scotland Ltd. 


\section{INTRODUCTION}

An evaluation carried out by CFA Archaeology Ltd at Hallhill Farm, Dunbar in May 2003 (Glendinning 2003) identified the remains of a rural medieval settlement and associated features, a sub-square enclosure and part of a long cist cemetery (illus 1).
Subsequently, an excavation was carried out during August and September 2003, in advance of housing construction by George Wimpey East Scotland Ltd. The results of this excavation form the subject of this report.

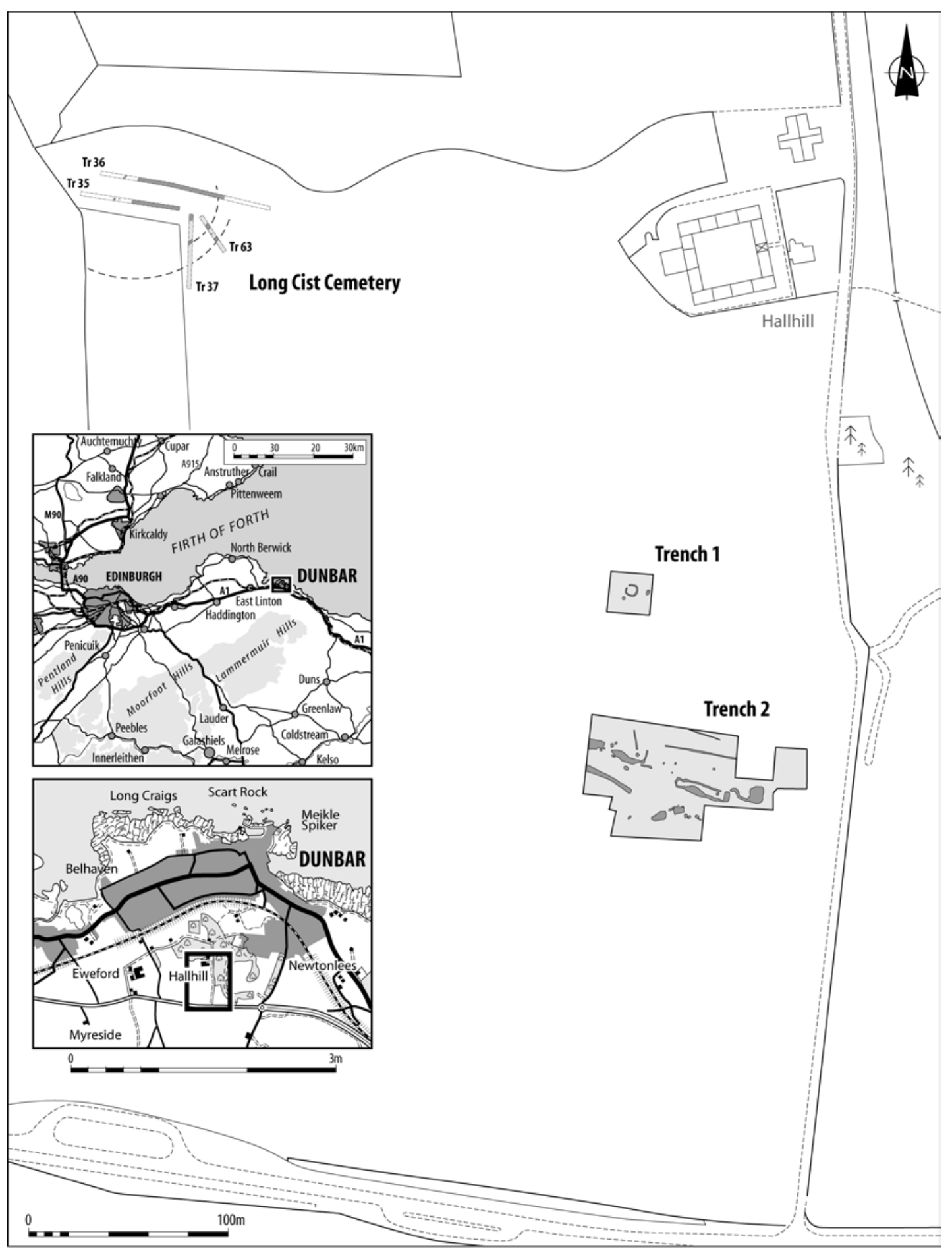

Illus 1 Site location plan 


\subsection{Site location, topography and geology}

The development area lay on the southern fringes of Dunbar (NGR NT 674 775; illus 1), and was located in an arable field to the south of Hallhill Steading. The site occupied the top of a low ridge running east to west at $c 25 \mathrm{~m}$ OD and sloping down gradually to the north and east. Topsoil was from 0.5 to $1.2 \mathrm{~m}$ in depth, and the subsoil varied from coarse stony gravel to fine-grained, dense sandy clay. The field had been extensively ploughed, and the archaeological remains had been significantly truncated or damaged as a result.

Hallhill was shown as Lochend Mains on the OS First Edition map of 1854, and the area was known as Lochend when John Adair published his survey of 1682. However, on Roy's map (1747-55) the area is designated 'Haughhill', and the name Hallhill appears on William Forrest's map of 1802 (Forrest 1802). On all of these maps the excavated area is shown as rough pasture or open land, even though rig and furrow predominates in the surrounding area on those maps which depict it. No historical research was undertaken as such work was beyond the remit of this project. However, the absence of any historical discussion here should not be taken to imply that there is no surviving documentary record relating to the site.

\subsection{Archaeological background}

The initial interest in this site arose from aerial photographs showing the remains of a possible circular or curvilinear double-ditched enclosure. The proximity of this enclosure to the proposed development area prompted a two-stage evaluation (Glendinning 2003; Curtis \& Johnson 2005) which identified a range of features.

The enclosure runs into the woods along the northern edge of the evaluation area. From the aerial photographs it appears to be double-ditched. Sections of its eastern side are clear but its western side is not visible, and therefore its true diameter is not known. The probable inner ditch of the enclosure was revealed in two trenches during the evaluation. The putative outer ditch of the enclosure was identified only in one trench. Both were $c 1.6 \mathrm{~m}$ wide, the inner surviving to $1.1 \mathrm{~m}$ deep and the outer to only $0.5 \mathrm{~m}$.

A cemetery comprising 32 long-cist burials and several concentrations of articulated bones was discovered within the arc of the enclosure ditches. The cist burials were aligned north-east to south-west, and the articulated bones appeared to represent the remains of dug graves without cists. Cemeteries of this type date from the early Christian period (4th-8th centuries $\mathrm{AD}$ ) and have been found elsewhere in the surrounding area, including to the east of Spott roundabout and on the site of Dunbar swimming pool (see Rees 2002 for overview), as well as more recently in western Scotland (eg Ardrossan,
Hatherley 2009). The cists and burials were outside the application area and were preserved in situ. All excavated human remains were re-interred without study. The curvilinear double-ditched enclosure was only partially evaluated due to agricultural considerations and further speculation regarding its nature is not possible with the present evidence.

Within the proposed development area, a series of pits and linear gullies was discovered, concentrated mainly around the low ridge running east to west across the south-east of the site. These features contained significant quantities of animal bone, shell and medieval pottery. The remains of a square-form enclosure with two nearby pits were also revealed, although no datable finds were recovered. The results of the evaluation prompted excavations.

\subsection{The excavation}

The aim of the excavation was to investigate fully the two areas of archaeological interest identified within the proposed development area (illus 1) which could not be preserved in situ. Trench 1 (illus 2) comprised an area of $20 \mathrm{~m}$ by $20 \mathrm{~m}$ excavated around the sub-square enclosure and nearby pits, with the objective of ascertaining their dates and any meaningful patterns. Trench 2 comprised an area containing medieval gullies, ditches and pits. A total of $c 4500 \mathrm{~m}^{2}$ was excavated to determine the extent and character of the features and reveal any other related archaeological remains. The extent of excavation was approved by East Lothian Council's heritage officer.

The topsoil was stripped under close archaeological scrutiny, using a mechanical excavator fitted with a smooth-bladed bucket. All exposed archaeological remains were subsequently cleaned and excavated by hand and surveyed using industry-standard methods and equipment. Features were not $100 \%$ excavated, rather, the excavation was targeted to understand the characteristics and stratigraphic relationships of features. The site was recorded by context, with composite planning. Environmental sampling targeted sealed and discrete deposits, while rejecting deposits which were subject to contamination. Stratigraphically secure deposits were also extensively sampled for finds recovery.

The archaeological remains comprised mainly negative features cut into the subsoil, most with silty or sandy fills which were heavily bioturbated and often merged with the overlying ploughsoil. Few upstanding remains were revealed; overall there was a marked absence of occupation or postabandonment deposits overlying the cut features. Ploughscores were visible in the subsoil surface over much of the site, particularly towards the west, where the topsoil was significantly thinner. This suggests a likelihood that any formerly stratified archaeological remains have been destroyed, leaving us with the fills of negative features cut into the natural subsoil. 
Routine soil samples were taken from deposits during the excavation. However, the majority of the deposits were highly bioturbated and were considered of no use for palaeoenvironmental analysis or for the recovery of dating evidence (Glendinning 2004). Samples from F10 and F24 were taken for the recovery of marine shell and were processed for this purpose.

\subsection{Archive}

The full project archive will be deposited with the Royal Commission on the Ancient and Historical Monuments of Scotland (RCAHMS). Finds disposal will be allocated through Treasure Trove procedures. Full specialist reports for all classes of material are provided within the site archive. 


\section{THE SQUARE ENCLOSURE, POSSIBLE GRAVE AND ASSOCIATED FEATURES (TRENCH 1)}

\subsection{Site description}

A square-form ditched enclosure measuring $c 5.25$ $\times 5.5 \mathrm{~m}$ externally was identified (F1) in Trench 1 (illus 2). There was no break in the ditch and no entrance or internal features were identified. The ditch cut (101) was $c 0.7 \mathrm{~m}$ wide and $0.3 \mathrm{~m}$ deep, with a U-shaped profile. The fill comprised fine-grained silt with sparse gravel and stone inclusions. A small quantity of animal bone (one cattle, three indeterminate mammal fragments; C Smith in archive) was recovered from the fill. A whetstone was found in this area during the evaluation topsoil strip. No datable finds or other organic material were recovered from the fill.

Two pits filled with stony silt were located within this trench, within $5 \mathrm{~m}$ of the enclosure. F2 was a shallow circular pit $c 1 \mathrm{~m}$ in diameter and $0.2 \mathrm{~m}$ deep, located to the south-west of the enclosure. It produced one small chunk of chert. A shallow oval pit, F3, was located to the east of the enclosure. It was aligned roughly north to south and measured
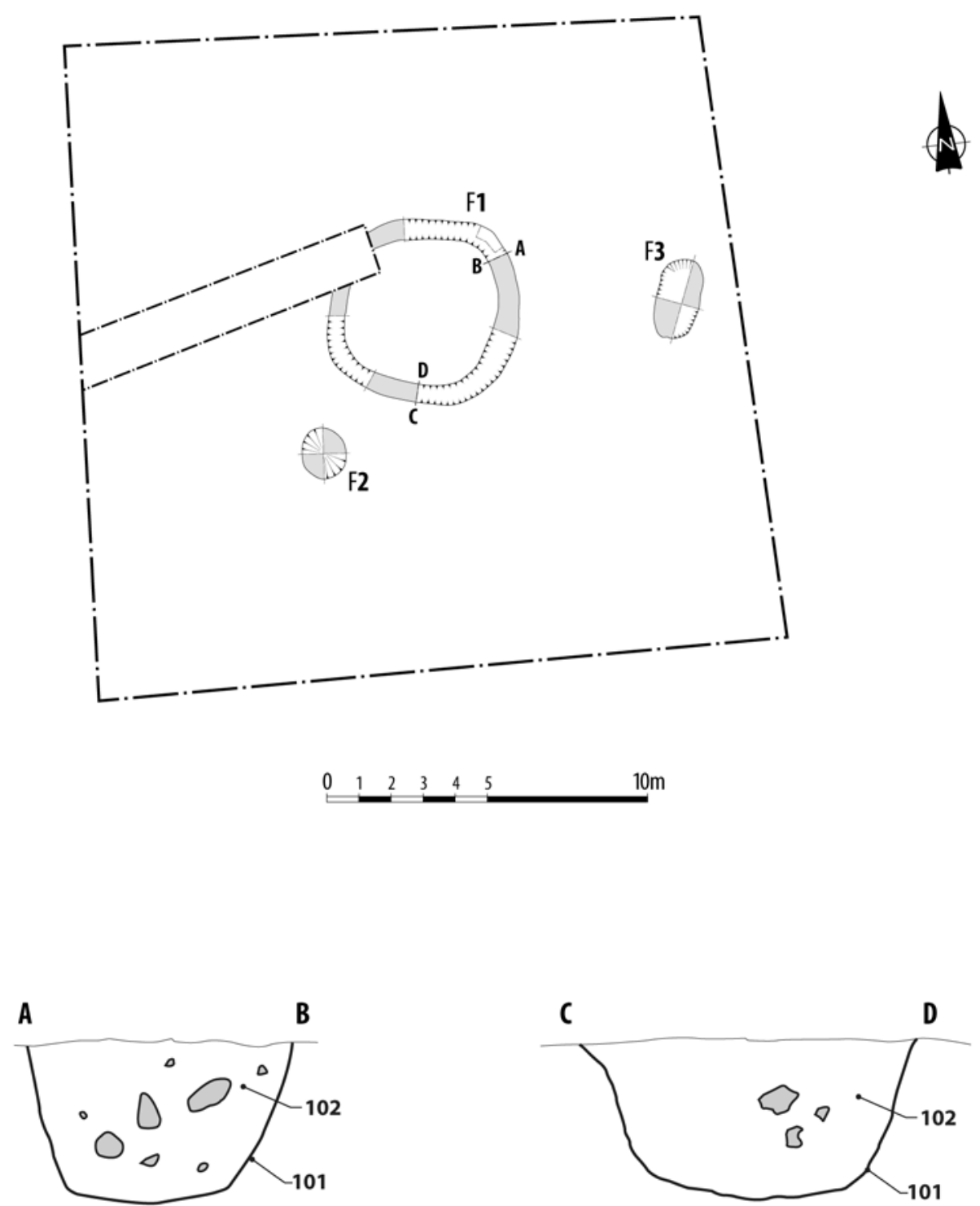

0 0.5 $1 \mathrm{~m}$

Illus 2 Trench 1 plan and sections 
$2.3 \mathrm{~m}$ long, $1.6 \mathrm{~m}$ wide and $0.5 \mathrm{~m}$ deep. It contained fragments of a human skeleton (left leg and feet) in very poor condition and was probably a truncated grave. Anderson (below) suggests that the skeleton may have been originally articulated.

\subsection{Human skeletal remains, by Sue Anderson}

Fragments of human bone were collected from F3. The pieces consisted of fragments of the lower left leg and both feet, specifically the lower left tibia, parts of the left talus and calcaneus, the proximal halves of the left first to third metatarsals, and the right proximal hallucial phalanx. The bones were probably articulated at the time of deposition, suggesting that the feature in which they were found was a grave.

The bones were in poor to fair condition, the long bone fragments consisting of flakes of the outermost layers only. The surfaces of the tarsal and metatarsal bones were also separating from the cancellous bone.

All epiphyses of the surviving bones were fully fused at the time of death, indicating that the individual was an adult. There were no specific ageing indicators, other than a lack of any degenerative change. Although nothing was measurable, the bones appeared to be of average size but were not robust. The individual may be female, but the evidence is inconclusive.

One genetic trait was present, namely a double anterior calcaneal facet; this trait is relatively common in most archaeological populations. There was an area of porosity on the joint surface of the distal left tibia, but this was likely to have been caused by post-mortem erosion.

In summary, the remains represent the lower left leg and one right toe of a mature adult, possibly female.

\subsection{Radiocarbon dating}

A piece of human bone was submitted for radiocarbon dating and returned a result of $2530 \pm 30 \mathrm{BP}$ (800-540 cal BC at $2 \sigma$ ), placing it in the Late Bronze Age or very early part of the Iron Age.

\subsection{Discussion}

Excavation of the square enclosure F1 did not produce any dating evidence or anything which might indicate its purpose. The ditch fill contained fragments of animal bone which could represent domestic refuse, but are most likely to have been deposited after the feature went out of use. Pits surrounded the feature, but the only finds of any significance from these were fragmentary human skeletal remains from pit F3, which probably formed part of an articulated burial. The bone was in very poor condition and the remainder of the skeleton is likely to have been lost due to the acidic nature of the soil.

The date of the bone from F3 is broadly contemporary with the dates from the pre-Christian burial pits at Dryburn Bridge (Dunwell 2007, table 11). Both F2 and F3 had similar characteristics to the burial pits there, being of similar size and shape to several of them, although F3 was longer (by some $40 \mathrm{~cm}$ ) than the longest burials at Dryburn Bridge. Unfortunately, with so little of the interment surviving, the position of the burial within the grave is unknown and further comparison with other excavated cemetery sites would be futile. 


\section{THE MEDIEVAL RURAL SETTLEMENT (TRENCH 2)}

An overall plan of Trench 2 is shown in illus 3. To the west, two broad linear gully systems (F5, F7) and several pits were revealed running roughly eastwest along the low ridge, with a ditch (F8) to the south. Two discrete structures (F13, F14) and several large pits (F15-18) were located to the south of the central area. The remains of an enclosure (F19) and a possible structure with stone footings (F24) were also revealed, situated slightly north-east of F13 and F14. Several pits of varying size and depth were also exposed to the north of F19 in the central part of the site. Two narrow gullies (F23 and F20) ran roughly east to west across the northern part of the site.

\section{1 'Sunken-floored' structures and associated features}

Two discrete structures, F13 and F14, were welldefined as irregular oval or sub-rectangular shallow depressions containing associated structural elements.

F13 (illus 4) was an irregular sub-rectangular feature measuring $c 7.5 \mathrm{~m}$ by $4 \mathrm{~m}$. It was defined by a shallow cut 1301 , with a level base $0.1 \mathrm{~m}$ deep. The base of the feature was cut by several irregular pits, situated mainly around the perimeter, and there were gravel patches on the surface. The pits measured between $0.7 \mathrm{~m}$ and $1.6 \mathrm{~m}$ in diameter and were $0.2 \mathrm{~m}$ to $0.5 \mathrm{~m}$ deep, steep or vertically sided and filled with dark silt and occasional large stones. Two pits at the west end of the feature produced interesting assemblages of finds. Pit 1313 contained several large stones in its upper fill, including two mortars/anvils and a pivot stone (illus 5). Large quantities of charcoal were recovered from pit 1315, as well as a decorated soapstone spindle whorl and 11 sherds of medieval pottery. A concentration of charcoal, ash and scorched sand, 1307, was located close to the centre of F13. The pits were sealed by a dense deposit of grey silt, 1302, which formed the fill of F13 and contained fragments of bone, charcoal and medieval pottery sherds. This fill underlay an extensive spread of large stones forming a layer up to $0.5 \mathrm{~m}$ deep, which was contained within the topsoil matrix. They became visible during excavation after removal of only $0.3 \mathrm{~m}$ depth of topsoil, and appeared to have been disturbed by plough action. Fragments of animal bone, medieval pottery sherds and an iron sickle blade were recovered from the base of the stones.

F14 (illus 6-7) was situated $4 \mathrm{~m}$ to the east of F13 and was a roughly sub-rectangular feature, aligned east-west and measuring $5.4 \mathrm{~m}$ by $3.5 \mathrm{~m}$; it had partial straight edges to the west, south and east sides with well-defined corners, but a less welldefined, curving northern edge which may have been truncated. The cut, 1401, was sharply defined with sloping sides and a flat base, and was $c 0.3 \mathrm{~m}$ in depth at the centre. It included a slight step along the straight edges, varying in width between $c 5 \mathrm{~cm}-20 \mathrm{~cm}$. The feature's north-eastern edge was defined by large stones set onto the subsoil surface. Two small stake-holes $(1405,1407)$ were revealed cut into the subsoil at the south-western corner, and another stake- or post-hole with packing stones (1411) was cut near the centre of the northern edge of the feature. There was an area of modern disturbance at the north-east corner of F14.

The floor of F14 was cut by sub-rectangular pit 1424, which was located at the west end of the structure, and abutted an oval patch of burnt sand (1425) to its east. Pit 1424 was filled with the same deposit which made up the primary fill of F14 (1404), a fine dark brown silt, suggesting that it was open during the life of the structure. Overlying this in the south-western quadrant was a $0.05 \mathrm{~m}$ thick layer of burnt material which contained charcoal (1403). The main fill of the feature was 1402, a homogenous spread of fine silt, which contained over 100 sherds of medieval pottery, a hammerstone, fragments of bone and charcoal fragments. This may represent an abandonment layer which formed after the structure went out of use.

At the north-west corner, F14 was cut by an elongated oval pit $1413(3 \mathrm{~m} \times 1 \mathrm{~m} \times 0.25 \mathrm{~m}$ in depth $)$. At its narrowest point, where it intersected the edge of F14, this pit contained two large stones, one of which has been identified as a discarded trough (1417; Jackson below). These either continued the line of the structure wall or, possibly, formed a threshold. Four stake-holes cut the base of the pit, three on the inside of F14 and one on the outside, in a linear arrangement. The two largest, one inside (1420) and one outside (1415), were approximately $1 \mathrm{~m}$ apart. The pit was filled with a dark sandy silt containing sparse limpet shells and occasional stones.

F14 was abutted by an oval pit (1426), measuring $2.3 \mathrm{~m} \times 1 \mathrm{~m}$ and $0.2 \mathrm{~m}$ deep, on its northern edge. It was filled with a compact dark silt containing a large quantity of periwinkle and limpet shells, fragments of animal bone and four sherds of medieval pottery.

To the east of F14, five pits were identified (illus 3 ). The closest, F15, consisted of one circular (1501; $2 \mathrm{~m}$ diameter, 0.7 deep) and one oval (1505; $c 2 \mathrm{~m} \times$ $1.2 \mathrm{~m}, c 0.5 \mathrm{~m}$ deep) pit, the former cutting the latter. Both had vertical sides and a slightly concave base. Pit 1501 produced over 100 sherds of medieval pottery and some animal bone, the majority from 


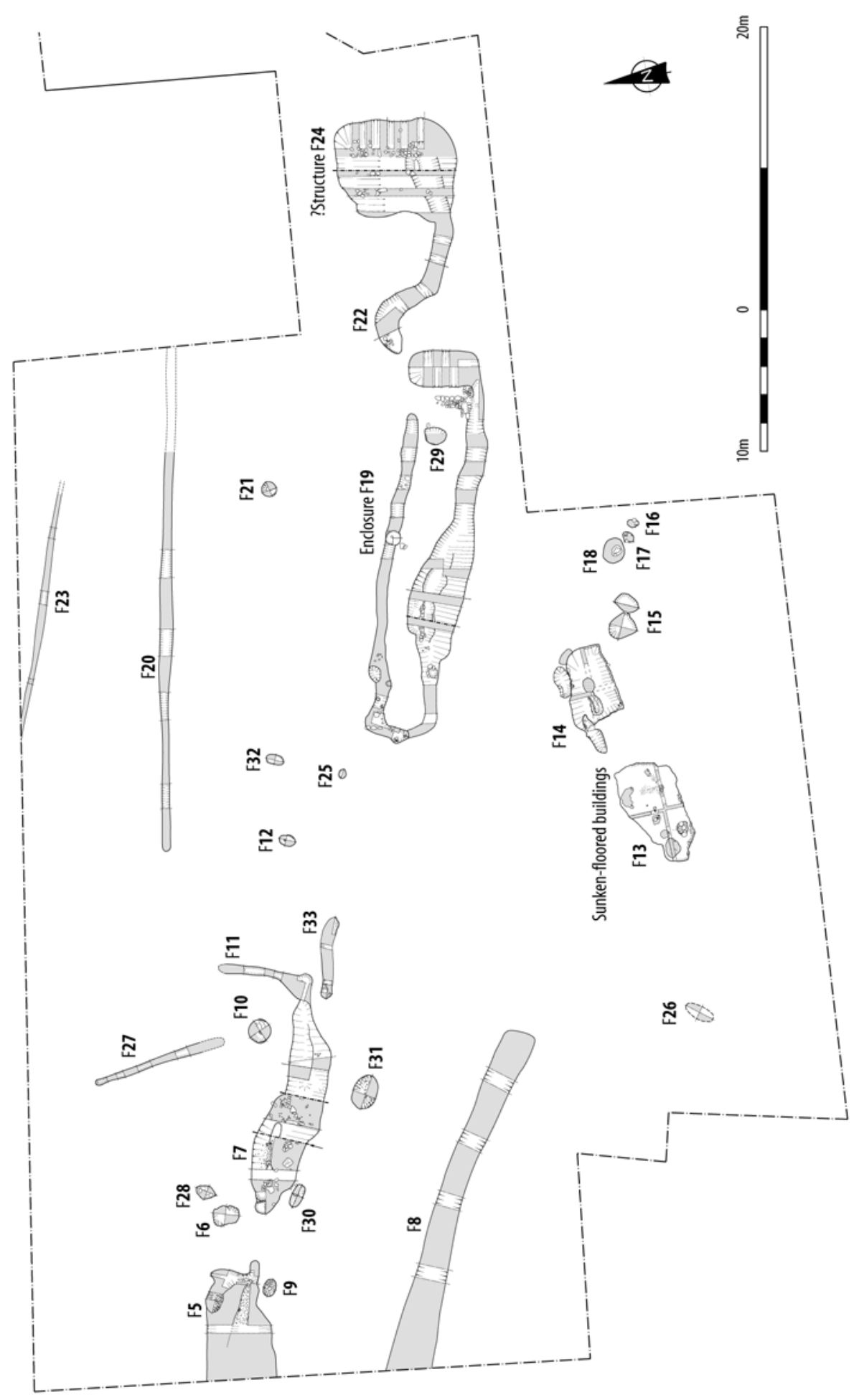

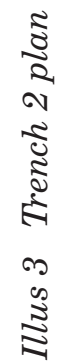


its primary fill. One sherd of modern earthenware from the upper fill is presumed intrusive. The two lower fills of 1505 were organic and peaty in nature, containing charcoal, medieval pottery and animal bone, and were covered by large angular stones, over which was a layer of dense silt.

Three further pits (F16-18) were situated adjacent to each other in a curvilinear arrangement and aligned roughly south-east to north-west. F16, the furthest east in the excavated area, was located $c 6 \mathrm{~m}$ east of the east end of F14. F16 was a circular pit (1601) measuring $0.8 \mathrm{~m}$ in diameter and reaching a depth of $0.9 \mathrm{~m}$ and was filled with sandy silt (1602). F17 was a roughly circular pit (1701) measuring $c 1 \mathrm{~m}$ in diameter and $0.6 \mathrm{~m}$ deep. The fill (1702) comprised fine sandy silt and contained several large angular stones (1703) in the base. F18 was a large circular pit (1801) $c 2 \mathrm{~m}$ in diameter and
$0.9 \mathrm{~m}$ deep. Much slumping of the sides of the pit had occurred and the cut was very unclear in places. It was filled with mixed sand and silt (1802), and contained three large flat stones in the base. All had been subject to bioturbation, and each produced a few fragments of medieval pottery. Fragments of charcoal were recovered from F18.

\subsection{Enclosure F19}

F19 (illus 8) was located towards the east end of the trench, $c 8 \mathrm{~m}$ to the north of F14. It comprised an elongated rectilinear enclosure defined by gully lines, on an approximately east to west alignment and measuring $c 27 \mathrm{~m}$ by $c 7 \mathrm{~m}$. The feature lay under an area of relatively shallow topsoil and had been severely disturbed and truncated by ploughing.

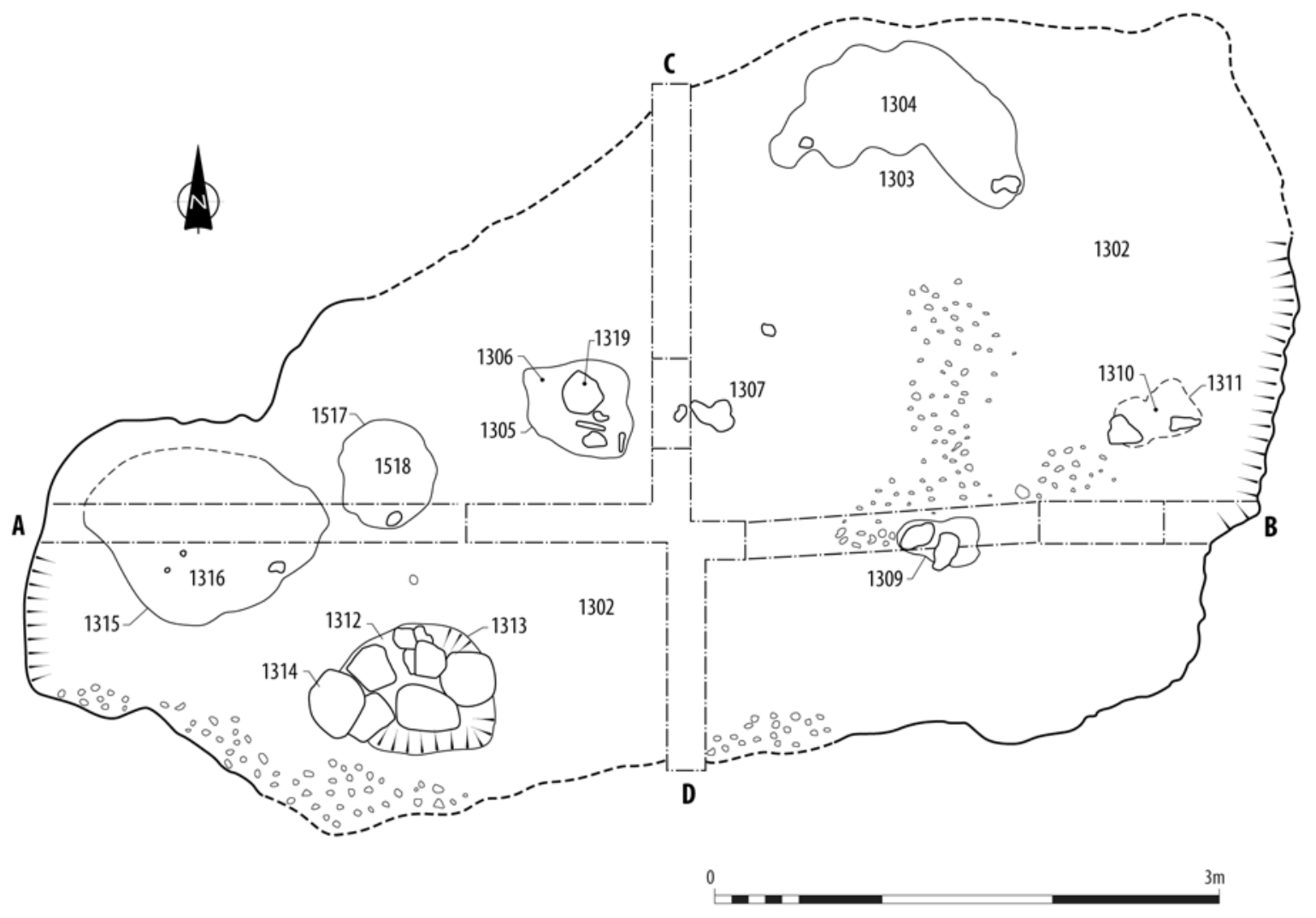

A
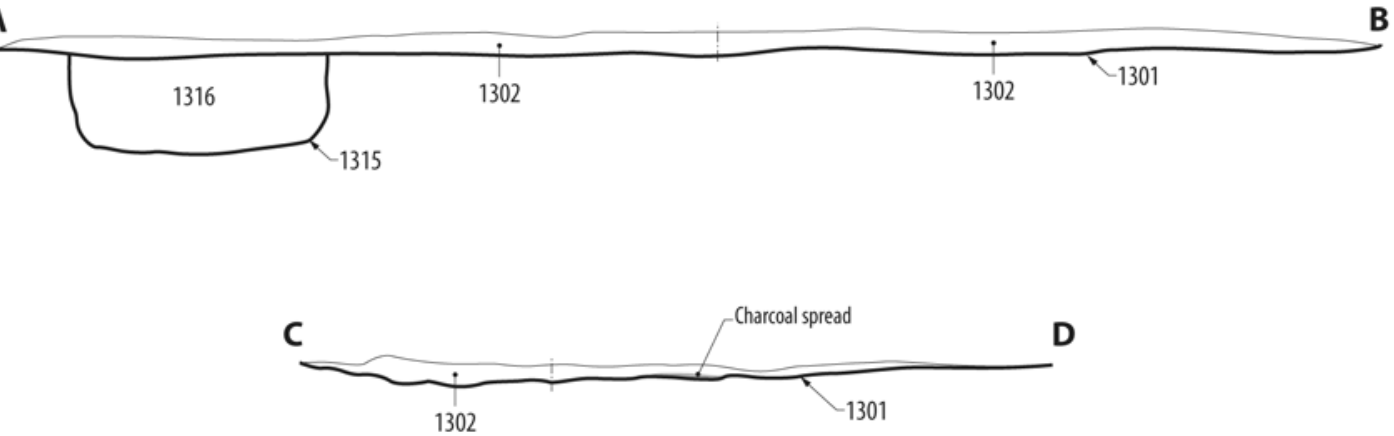

Illus 4 Plan and sections of F13 


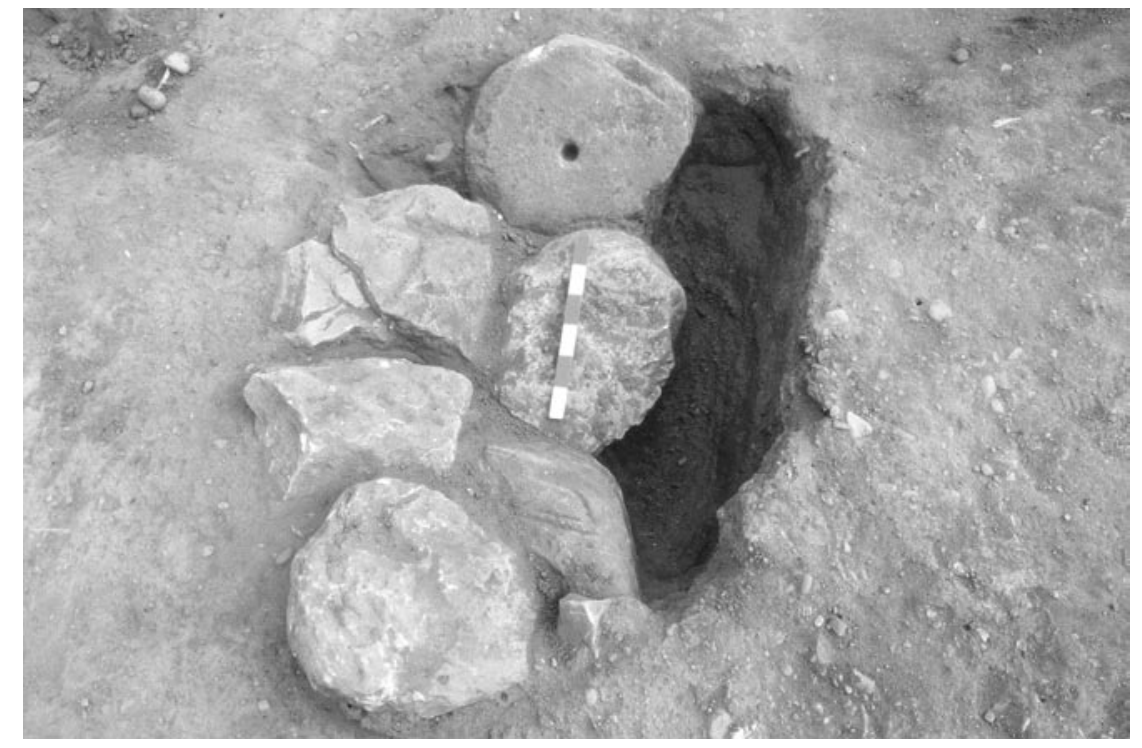

Illus 5 Pit 1313 half-sectioned with in situ stones in upper fill visible including pivot stone

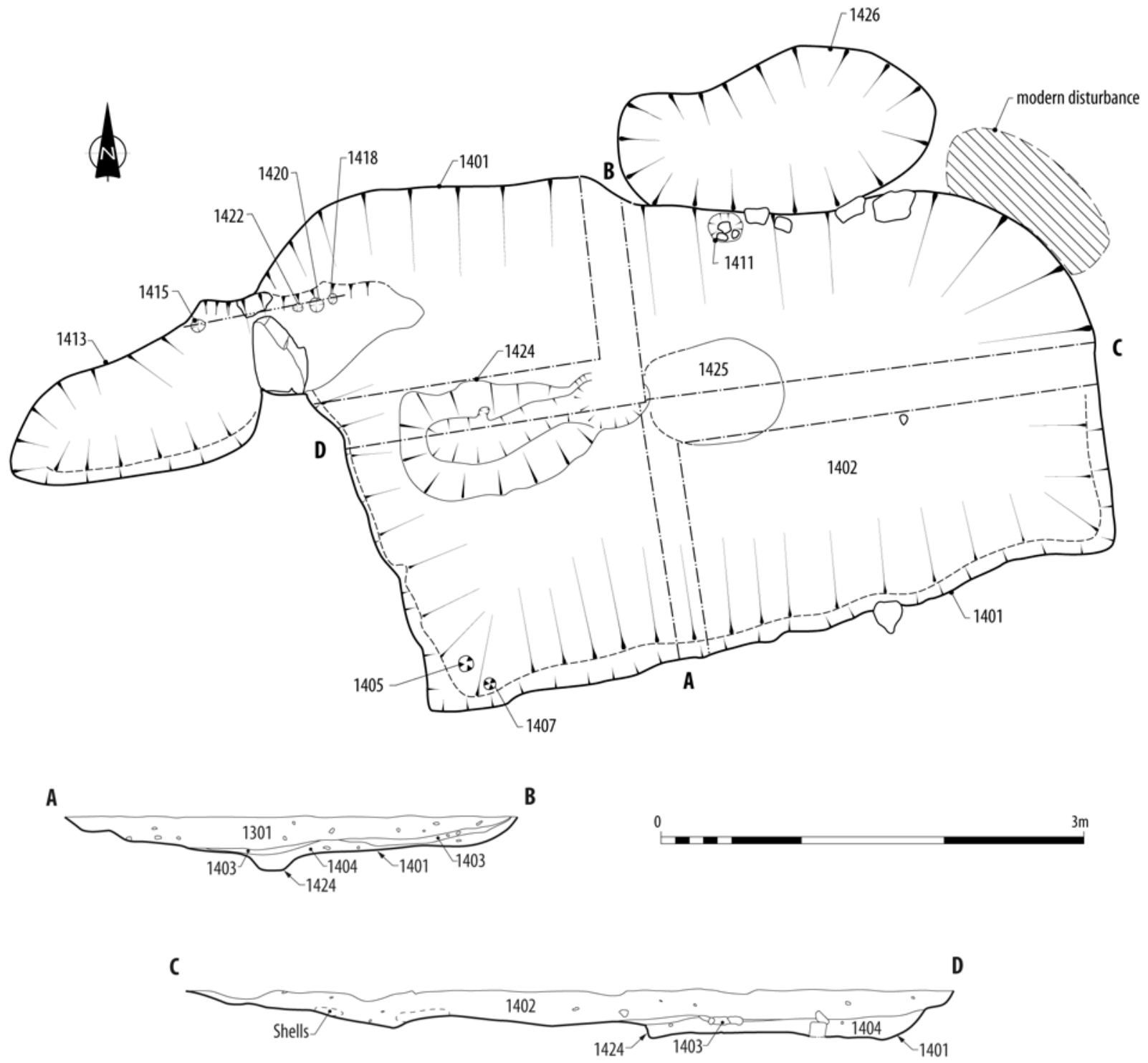

Illus 6 Plan and sections of F14 


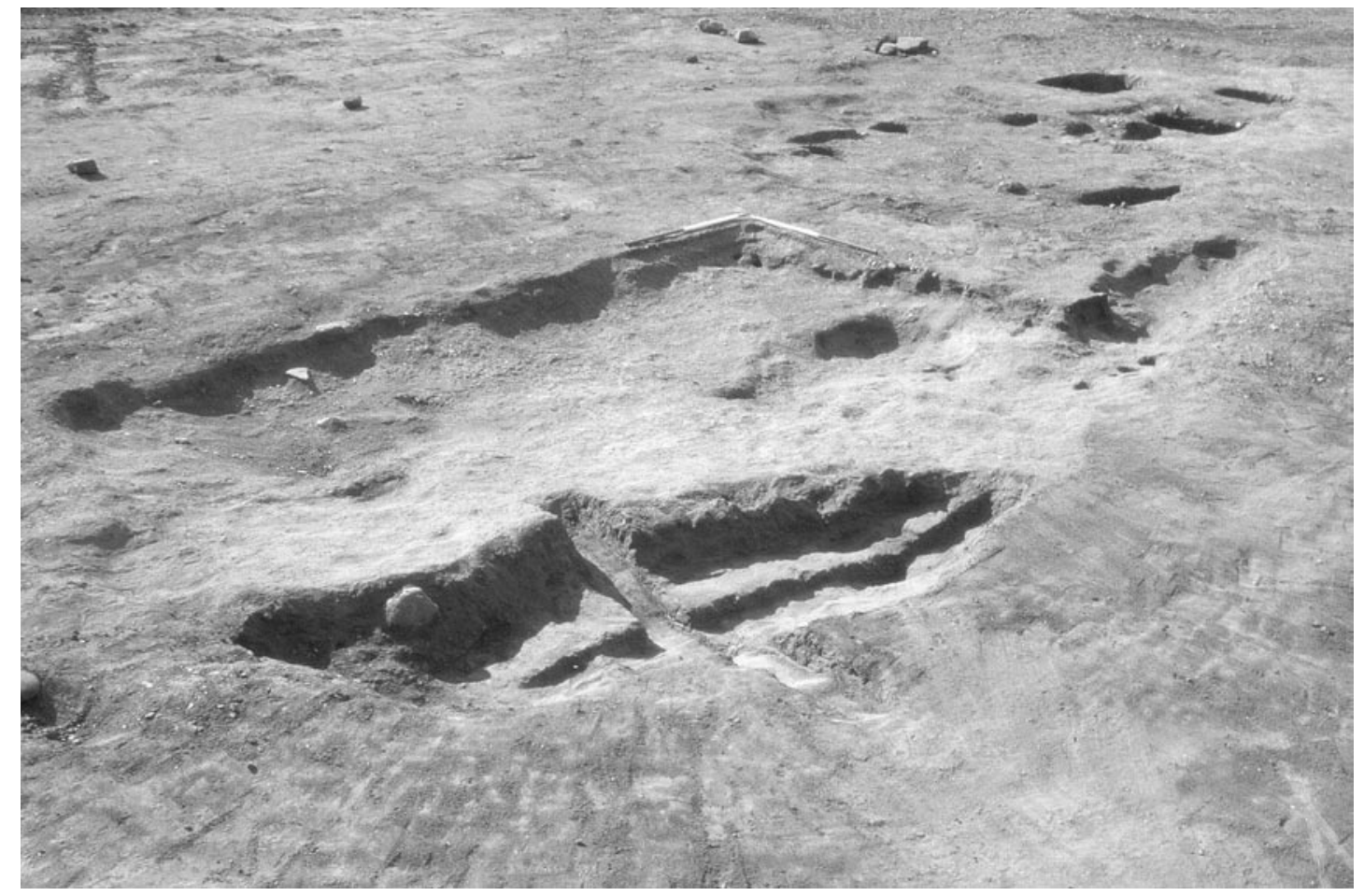

Illus 7 South-facing view of F14 with pit 1426 in the foreground. The pits in the floor of F13 can be seen to the top right of the picture

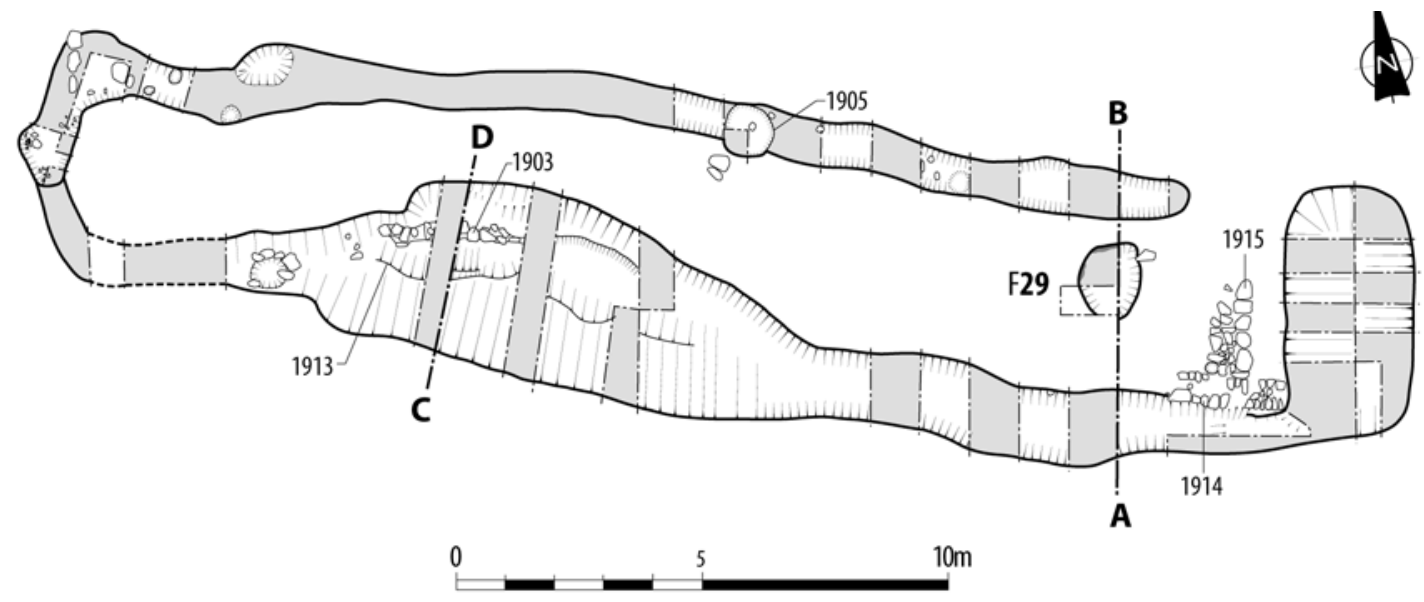

A
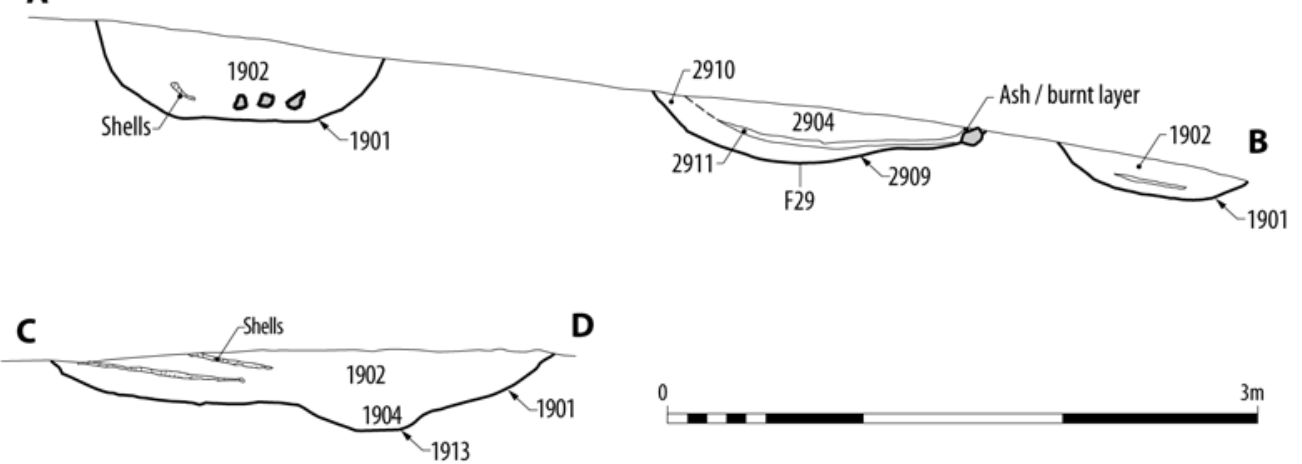

D

Illus 8 Plan and sections of F19 


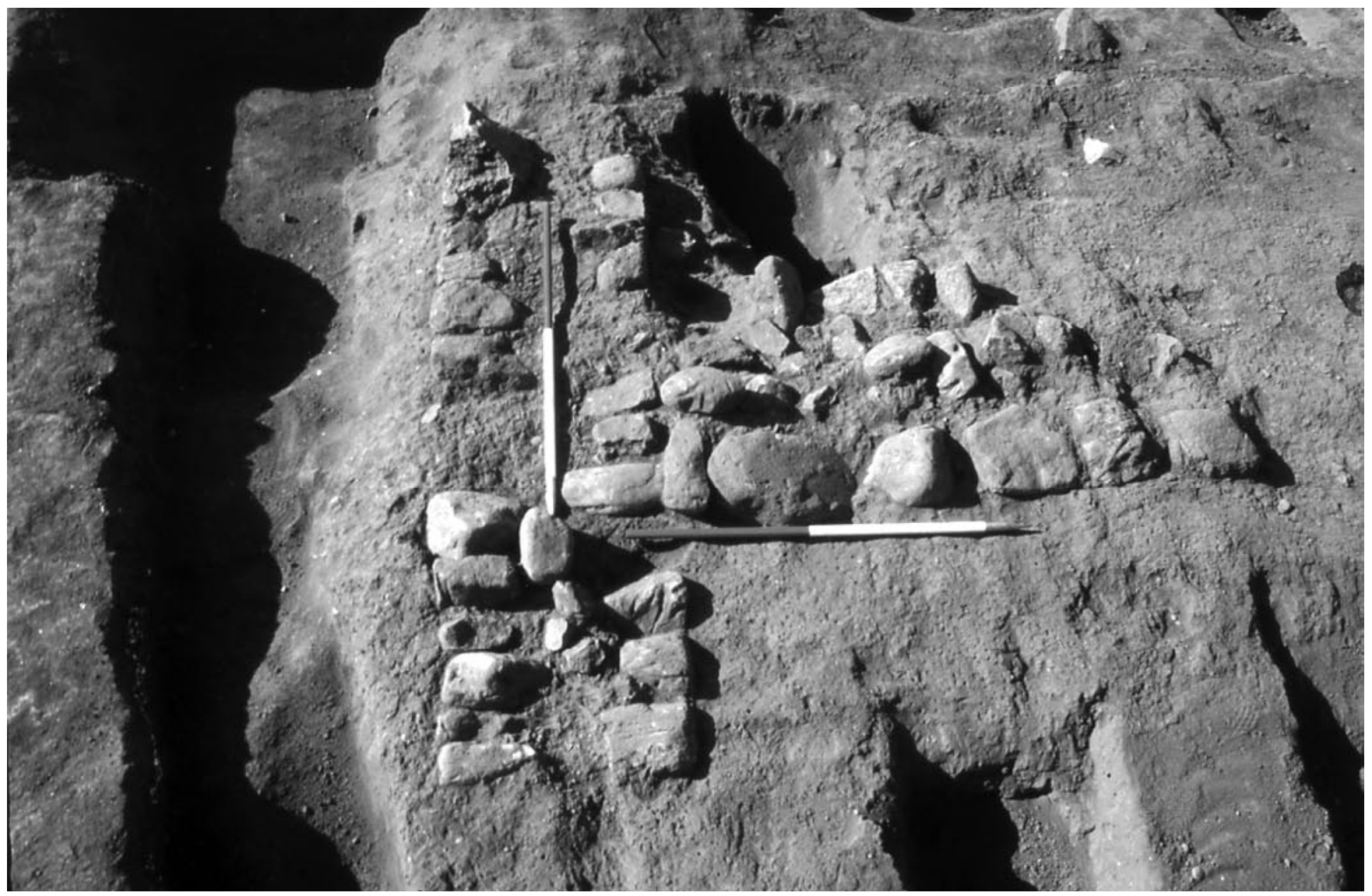

Illus 9 Wall 1915

The gullies and much of the interior of the feature were sealed by firm dark silt (1902). This contained extensive stone tumble within the interior of the enclosure, with a particular concentration around the north-west corner. It may represent a post-abandonment layer.

Two parallel gullies aligned approximately east to west were linked at the west end, forming a rectilinear enclosure with a break at the north-east corner, possibly representing an entrance. The enclosure was less well defined towards its east end. The gully defining the north and west edges of the feature measured $c 1 \mathrm{~m}$ wide by $c 0.15 \mathrm{~m}$ deep. The cut (1901) had shallow sloping sides and an irregular base. A circular pit (1905), c 1m in diameter, had been cut into the north gully approximately midway along its length. It had steeply sloping sides and a concave base at a depth of $0.4 \mathrm{~m}$. It was filled with dark, organic-rich silt (1906). No finds were recovered from the fill.

On the south side, the gully became significantly deeper and wider, measuring $c 1.4 \mathrm{~m}$ wide by $c 0.7 \mathrm{~m}$ deep. The fill contained several thin lenses of shell. A ditch had been re-cut (1913) near the centre of the south gully, at the point close to the centre where it widened to $3.5 \mathrm{~m}$ for a length of $6 \mathrm{~m}$. The re-cut was $c$ $6.5 \mathrm{~m}$ in length by $c 1 \mathrm{~m}$ wide and was $0.6 \mathrm{~m}$ deep with steeply sloping sides and a concave base. It lacked defined termini at either end, and merged into the main gully 1901 . The fill of the re-cut (1904) was a dark grey silt containing occasional shells. It had merged with 1902 due to bioturbation and leaching. Several large stones (1903) were contained within the fill, which may represent tumble from a possible former structure.

The gully defining the east edge of the feature turned $90^{\circ}$ to the north from the south gully and terminated close to F22. Here, the cut had shallow sloping sides and a concave base with a rounded terminus, and measured $c 2 \mathrm{~m}$ wide and $0.3 \mathrm{~m}$ deep. It seems likely that it formed a continuation of the gully, and it may have run towards F22 as a waste drain. Alternatively, the gap between its terminus and the east end of the north gully may represent an entrance.

Two wall footings forming a $90^{\circ}$ return were discovered within the enclosure at its south-east corner (illus 9). Footing 1914 was aligned parallel to the southern gully and was constructed as two parallel rows of large sandstone blocks set onto the subsoil surface, forming a double-skinned cavity foundation. It extended for $c 2.3 \mathrm{~m}$ and was $0.7 \mathrm{~m}$ wide. The other footing (1915) abutted this on its north side at a right-angle. It was built from large blocky sandstones set onto the subsoil surface without any definite structural pattern other than their 

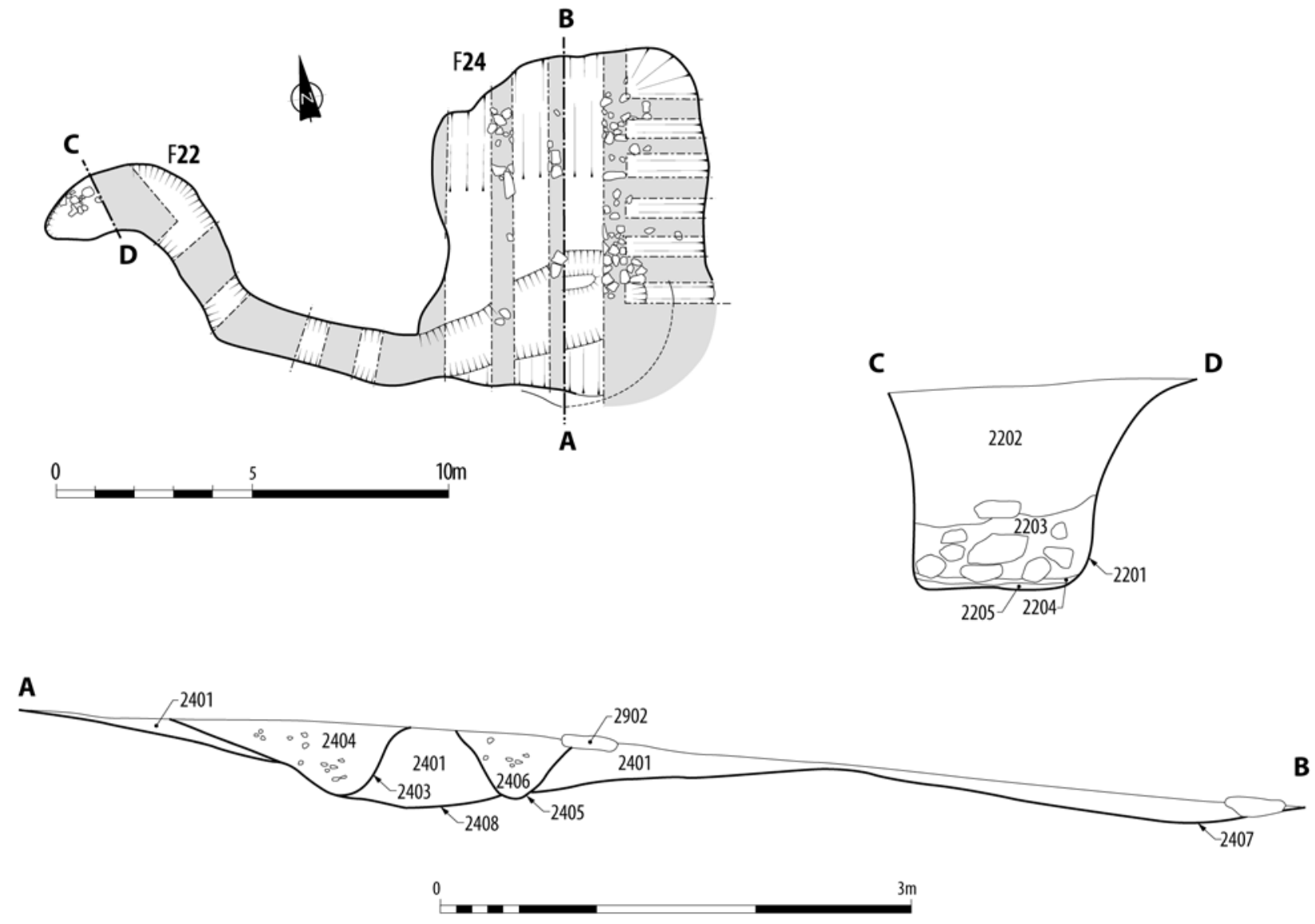

Illus 10 Plan and sections of F22 / F24

alignment. This footing extended for $c 2 \mathrm{~m}$ and was $0.7 \mathrm{~m}$ wide. There was no evidence of a foundation trench for these stones.

A possible hearth pit (F29) was discovered inside the enclosure, located towards the east end of F19. It was cut into the subsoil and measured $1.4 \mathrm{~m}$ in diameter by $0.6 \mathrm{~m}$ deep. The primary fill (2910) comprised a dark silt deposit $0.2 \mathrm{~m}$ thick, which contained charcoal and burnt material. Overlying this was a $0.1 \mathrm{~m}$-thick deposit of charcoal-rich burnt material (2911). Above this was a dark silt fill (2904). It is possible that the thin layer of charcoalrich burnt material represents sweepings or refuse rather than in situ burning.

Finds from F19 included over 300 sherds of medieval pottery, over 500 bone fragments, a fragment of painted window glass, two stone mortars, a knife, an annular buckle and a fragment of buckle plate. All datable objects from the feature appear to belong to the 13th-14th centuries.

One possible interpretation of this feature is that the shallow gullies were dug to provide material to create a level house platform on which to build at least one stone-footed structure. The profiles of the gullies, which have shallow outer sides and slightly steeper inner sides levelling off at the top, would be compatible with this interpretation. This suggestion is discussed further below. It is also possible that the gullies served as waste drains running alongside the structure.

\subsection{Other structures}

F24 (illus 10-11) was defined by a sub-rectangular hollow (2408) aligned approximately north-south and measuring $c 8.7 \mathrm{~m}$ by $7 \mathrm{~m}$, with gently sloping sides and a depth of 0.15 to $0.4 \mathrm{~m}$. It was filled with firm dark silt (2401) which merged with the undisturbed topsoil extant over this part of the site. Fragments of animal bone, a copper alloy buckle frame, an iron blade, a grinding stone and over 100 sherds of medieval pottery were recovered from the fill.

On the south side of the hollow, a curvilinear gully, 2403, cut the silt fill and ran out of the hollow towards the north-west for $c 15 \mathrm{~m}$, curving round and merging with F22 (see below). The gully was $1.1 \mathrm{~m}$ wide and $0.5 \mathrm{~m}$ deep with a U-shaped profile, and was filled with dark silt (2404) which contained a high concentration of shells, as well as some medieval pottery. To the north of the east end of gully 2403 , a narrower gully (2405) measuring $0.7 \mathrm{~m}$ wide and $0.4 \mathrm{~m}$ deep ran parallel for $c 4 \mathrm{~m}$, merging at either end. The relationship between the two was unclear. The fill of 2405 was the same as 2403 in 


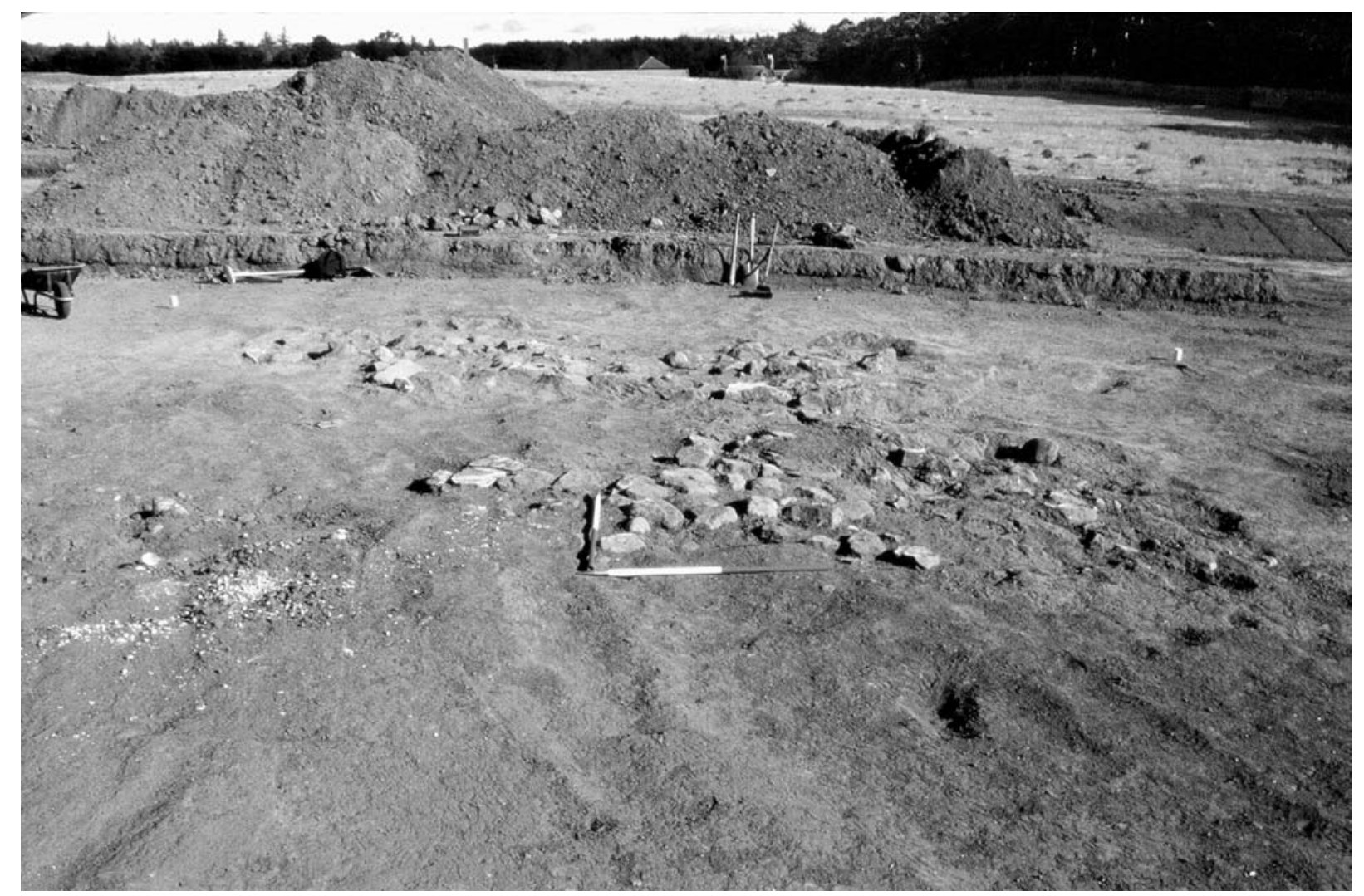

Illus 11 North-facing surface view of F24

general make-up, although it contained significantly less shell and no pottery.

A spread of stones, 2402, was apparently contained within fill 2401, although few of the stones rested on the floor of the hollow. On plan they suggested a rectilinear or square structure, but some of the stones may represent paving or tumble rather than footings. It seems likely that the southern edge of the stones was delineated by gully 2403 , although some lay above its fill, possibly due to later tumble and plough action. They did appear to overlie the fill of 2405, however. At the northern side, large stones were set directly on the subsoil surface, and the feature appeared to be defined by a discontinuous vestigial shallow depression (2407). This may represent a former foundation ditch for a stone wall, although too little survived to be certain of this interpretation.

F22 (illus 10) comprised a large oval pit situated at the end of the ditch running from F24. The pit measured $c 2 \mathrm{~m}$ long, $1.8 \mathrm{~m}$ wide and $1 \mathrm{~m}$ deep, and was aligned ENE-WSW. The cut (2201) of the pit was vertically-sided with a flat base. The primary fill was a black organic peat $c 0.03 \mathrm{~m}$ thick (2205), which underlay a $0.1 \mathrm{~m}$ deposit of degraded shells contained within loose sandy clay (2204). This shellrich deposit underlay a $0.5 \mathrm{~m}$-thick layer of large sub-angular stones contained within a matrix of grey gritty clay (2203). Over this was a deposit of dense silt (2202) containing limpet and periwinkle shells. Fragments of bone and medieval pottery sherds were recovered from the upper deposit, which merged with the fill of gully 2405 .

It seems likely that $\mathrm{F} 22$ formed a sump or soakaway for gully 2405, which may have functioned as a drain. The stone spread, though vestigial, is likely to represent another stone-footed structure similar to that identified in F19. Whether the two structures were contemporary is uncertain, as the gully cut the fill of F24. It is not clear whether the fill represents an abandonment layer within a hollow around the putative stone structure, or whether it was intentionally backfilled before the construction of the possible drain.

\subsection{Complex of features to the west of the site}

A series of ditches and pits was excavated in the western third of the site (illus 3). Three primary features comprising large linear gullies (F5, F7 \& F8) aligned roughly east to west occupied the west of the site.

F5 comprised a shallow irregular gully extending c $7 \mathrm{~m}$ from the western baulk of the trench. It measured up to $c 4.9 \mathrm{~m}$ wide and had a possible deeper re-cut along its south edge, measuring up to $3 \mathrm{~m}$ wide and $0.3 \mathrm{~m}$ deep. The gully terminus was irregular in plan and featured a possibly re-cut curvilinear slot orientated north-south and measuring $c 5 \mathrm{~m}$ by $1 \mathrm{~m}$ and up to $0.3 \mathrm{~m}$ deep. The fill of F5 was a variable compact stony silt which contained 

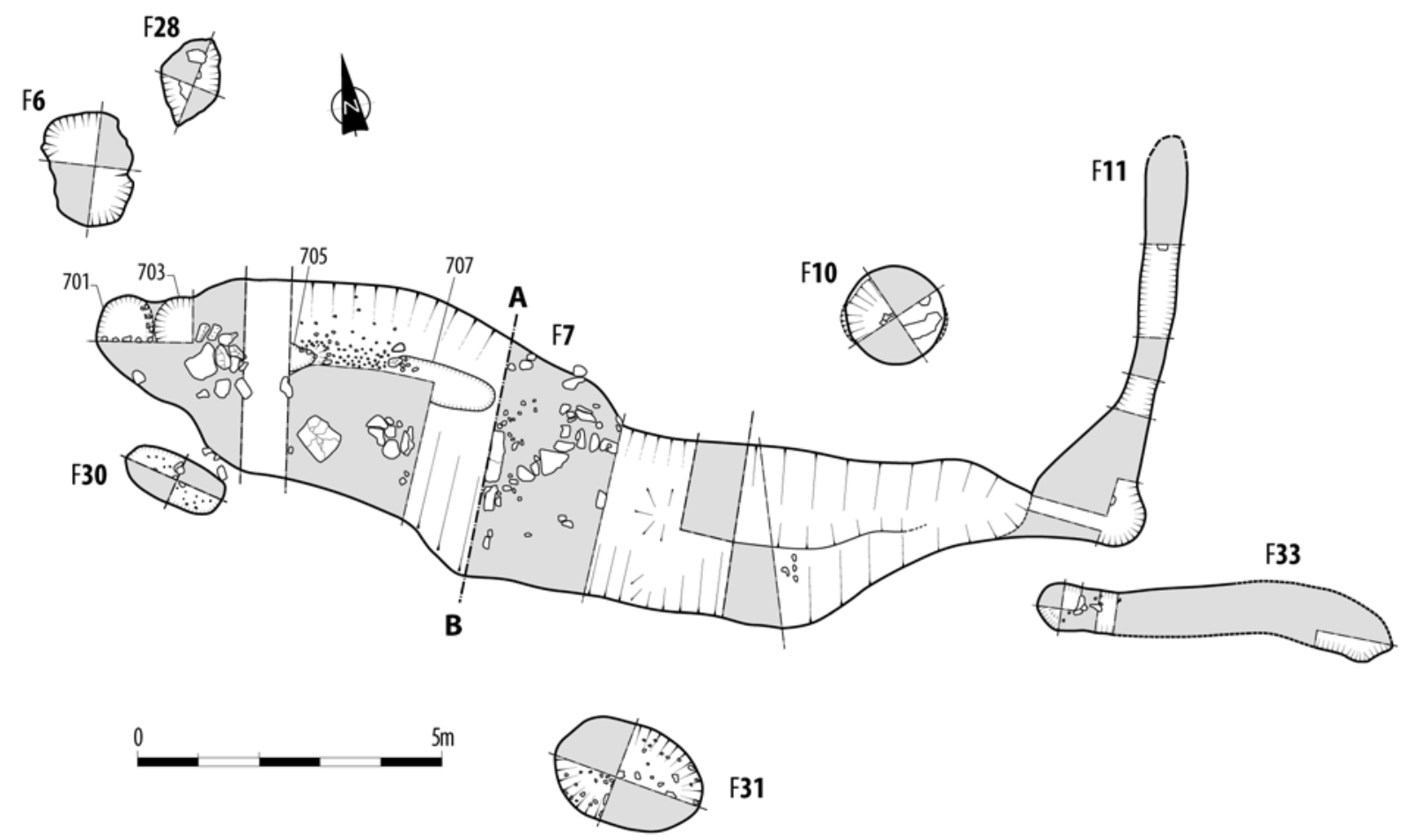

F31
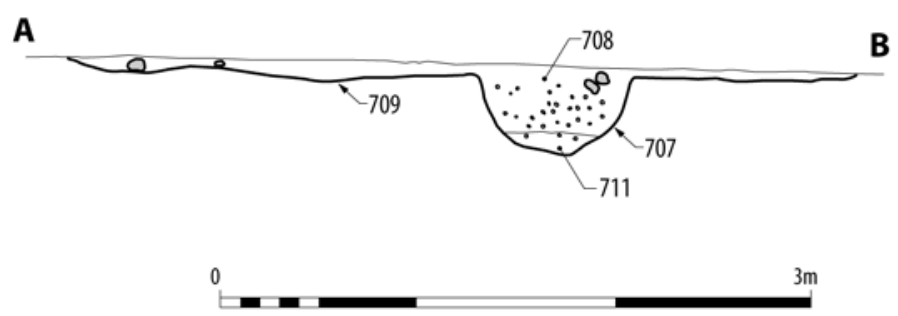

Illus 12 Plan and section of F7

occasional shell inclusions. No stratigraphical relationships between the possible re-cuts and the main gully could be discerned with any certainty from the fill. Fragments of animal teeth and bones and sherds of medieval pottery were recovered from the main fill. A copper alloy ?token was recovered from the fill of the narrow linear slot.

F7 (illus 12) was on the same alignment as F5, situated $c 5 \mathrm{~m}$ to its east. It consisted of a series of oval pits and linear ditches cut within a broad, shallow gully measuring $c 13.5 \mathrm{~m}$ long and $3-4 \mathrm{~m}$ wide. Due to bioturbation and soil leaching it was not possible to resolve stratigraphical relationships between the individual pits and ditches. The cut (709) of the main gully varied in depth from $0.2 \mathrm{~m}$ to $0.6 \mathrm{~m}$, with very shallow sloping edges and an irregular concave base. The eastern terminus narrowed to $1.5 \mathrm{~m}$ and merged with the southern terminus of F11 (below). The fill was compact grey silt (710) throughout, which contained several large worked stones including two pivot stones, although they were not in situ. Finds included animal bones, sherds of medieval and post-medieval pottery and a copper wire loop. The upper fill had been disturbed by ploughing so finds from there must be viewed as being less than secure.

Four pits were cut into the base of F7. The western terminus of the feature was defined by two rounded pits $(701,703)$ with steep edges and slightly concave bases, each measuring $c 1 \mathrm{~m}$ in diameter and $0.4 \mathrm{~m}$ deep. The two other pits $(705,707)$ were oval in plan, with steep sides and irregular concave bases, and measured $c 1.8 \mathrm{~m}$ by $0.6 \mathrm{~m}$ and $0.6 \mathrm{~m}$ deep. The pits were filled with compact grey gravelly silt $(702,704$, $706,708)$ which was indistinguishable from the surrounding fill of the main gully (710). One pit (707) contained medieval pottery in its fill.

A linear ditch (F11), aligned north to south, was located at the east end of F7 and filled with dark stony silt (1102). It measured $c 15 \mathrm{~m}$ long by $0.5 \mathrm{~m}$ wide and $0.4 \mathrm{~m}$ deep, although its northern extent was truncated out and its southern extent merged with the eastern edge of F7. Bone, medieval pottery sherds and charcoal were recovered from 
the fill. Its stratigraphical relationship with F7 was unclear due to the homogeneity of the fills and truncation.

There is a possibility that F7 formed the south side of another structure similar to F19, possibly with an open north side. The north-south gullies at the east ends of F5 and F7 could then form the east and west ends of the 'enclosure' which was dug to form another house platform. At $23 \mathrm{~m}$ in length, this would be slightly shorter than F19, but the surviving length of F11 suggests that it could have been slightly wider, perhaps up to $7 \mathrm{~m}$. However, the presence of pits within the gully base is a defining attribute of F7, and is absent from the ditches forming F19, so it is equally likely that F7 represents a different type of feature.

F8 (illus 3) was a linear ditch which ran roughly ENE to WSW, extending $25 \mathrm{~m}$ from the western baulk of the trench, $c 10 \mathrm{~m}$ to the south of F7. It was $c 1 \mathrm{~m}$ wide and $c 0.3 \mathrm{~m}$ deep, and had sloping sides with a shallow concave base. Limpet shells accounted for $c 50 \%$ of the loose stony fill. It appeared to have been truncated at the west so it may have extended further. A few sherds of medieval and post-medieval pottery and animal bone fragments were recovered from the fill.

Several other ditches and pits were located in the west of the site (illus 3). A shallow linear ditch (F33) was situated to the east of F7, on the same alignment as the main gully of F7. It measured $5.9 \mathrm{~m}$ by $0.7 \mathrm{~m}$ and $0.25 \mathrm{~m}$ deep and had a dark stony silt fill containing medieval pottery. A NNW-SSE aligned ditch (F27) was located to the north of F7, $c 6 \mathrm{~m}$ by $0.3 \mathrm{~m}$ and $0.15 \mathrm{~m}$ deep and had a stony silt fill.

Several circular and oval pits (F6, F9, F10, F28,
F30, F31) measuring between 1.2 and $2.5 \mathrm{~m}$ in diameter were situated close to F5 and F7, though without any stratigraphical association. Small quantities of medieval pottery sherds, animal bone fragments, degraded shell fragments, mortar and charcoal were recovered from several of the pit fills and a large flat stone was found in the base of F28, which may represent a padstone.

\subsection{Other features}

Four pits and two narrow ditches occupied the north of the site (illus 3 ).

The ditches (F20, F23) were visible for up to $25 \mathrm{~m}$ running east to west along the north edge of the site. F20 was $0.3 \mathrm{~m}$ wide and $c 0.2 \mathrm{~m}$ deep, and was filled with fine sandy silt, from which sherds of medieval pottery were recovered. F23 had been truncated and survived to less than $0.01 \mathrm{~m}$ deep, and was only faintly visible in damp conditions along its entire length, although a hammerstone/pounder and eight sherds of medieval pottery were recovered from the fill.

The pits (F12, F21, F25, F32) were sub-circular to oval and were spread between F20 and F19. They measured between 0.6 and $1.4 \mathrm{~m}$ in diameter and up to $0.3 \mathrm{~m}$ deep. The fill of F12 contained animal bone fragments and medieval pottery, F32 contained limpet shells and thin horizontal lenses of ash and F21 contained charcoal, fragments of a copper alloy vessel and medieval pottery sherds.

An isolated oval pit (F26) was located in the southwest of the site. It was $1.8 \mathrm{~m}$ by $1 \mathrm{~m}$ and $0.2 \mathrm{~m}$ deep, and filled with fine stony silt. 


\section{ARTEFACTUAL \& ENVIRONMENTAL EVIDENCE (TRENCH 2)}

\subsection{Medieval pottery, by Derek Hall}

The 1053 sherds from this excavation were examined by eye and $\mathrm{a} \times 10$ hand lens and where possible identified to a known fabric type.

Nine hundred and ninety-nine of the sherds are variations of Scottish White Gritty Ware (illus 1314, Nos 1-45), assumed to be a local product that currently has only one identified production site, at Colstoun near Haddington, although it is highly likely that many more await discovery (Hall 2004). Without chemical analysis it is very difficult to tie this fabric down to a specific production site, although it is notable that none of the variations identified in this assemblage match those identified from Colstoun, where the presence of iron concentrations in some of the clays gives this fabric a pink to red tinge. The vessel forms in this fabric are dominated by glazed jugs by a ratio of two to one, and there is a single example of a dripping pan from F24.

Scottish Redware was also present in the Colstoun kiln assemblage, although it is not known whether it was locally produced or imported from production centres further north (Hall 1998). All of the 29 sherds from Hallhill are from glazed jugs (illus 14, nos 46-47).

Rhenish stonewares, imported German fabrics which become common from $c 1350$ onwards and are common finds in the burghs of Perth, Leith and Edinburgh, were represented here by a single sherd from the surface of F7.

There are nine sherds which are not readily identifiable to known fabric types (illus 14 , nos 48 to 49). Some of these may be imports, probably from England, but are too small to warrant accurate identification. Of most interest in this small group is the single sherd from a glazed vessel with a stamped floral decoration (no. 49).

Modern ceramics were represented by nine sherds of brown-glazed earthenware, two of salt-glazed stoneware and four of white earthenware, all of which date to the 19th century and are presumably from manuring of the field, though they were intrusive in earlier features.

\section{Catalogue (illus 13-14)}

Scottish White Gritty Ware: Fabric 1

1 Rimsherd from unglazed jar. F8, SF 018.

2 Rimsherd from unglazed jar. F14, fill 1402, SF 125.

3 Rimsherd from unglazed jar. F19, upper fill 1904, SF 198.
4 Rimsherd from unglazed jar. F19, upper fill 1904, SF 198.

5 Rimsherd from unglazed jar. F11, gully fill 1102, SF 056.

6 Rimsherd from unglazed jar. F33, fill 716, SF 111.

7 Rimsherd from unglazed jar. Trench 2, SF 202.

8 Rimsherd from unglazed jar. F24, SF 036.

9 Rimsherd from unglazed jar. F7, pit fill 702, SF 054.

10 Rimsherd from unglazed jar. F15, pit fill 1506, SF 147.

11 Rimsherd from unglazed jar. with pronounced cordon around vessel. F7, SF 204.

12 Slightly frilled rimsherd from unglazed jar. F24, SF 036.

13 Slightly frilled rimsherd from unglazed jar. F14, pit fill 1427, SF 180.

14 Rim and ribbed strap handle from jug splashglazed green. F8, ditch fill 808, SF 079.

15 Narrow unglazed ribbed strap handle. F19, SF 170.

16 Bodysherd from green-glazed jug decorated with brown-glazed applied strips and pellets. F19, SF 008.

17 Strap handle and junction from jar with external smoke blackening. F19, SF 162.

18 Strap handle from green-glazed jug. F19, fill 1901, SF 230.

19 Basal angle from jar with external smoke blackening. F19 surface.

20 Basal angle from unglazed jug. F13, pit 1315, SF 130.

21 Basal angle from unglazed jug. Unstratified, SF 202.

Scottish White Gritty Ware: Fabric 2

22 Bodysherd from green-glazed jug decorated with brown-glazed strips and embossed pellets. F19, upper fill 1904.

23 Bodysherd from green-glazed jug decorated with impressed 'hollows'. F19 SE surface.

24 Bodysherd from green-glazed jug decorated with rouletted decoration. F19, SF 172.

25 Bodysherd from green-glazed jug decorated with rouletted decoration. F24, SF 036.

26 Bodysherd from green-glazed jug decorated with incised decoration. F16, pit fill 1602, SF 142.

27 Narrow strap handle from jug with patches of green glaze. F7, SF 208.

28 Ribbed strap handle from green-glazed jug. F24, SF 036.

29 Basal angle from unglazed vessel with patch of green glaze on base. F19, SF 172. 

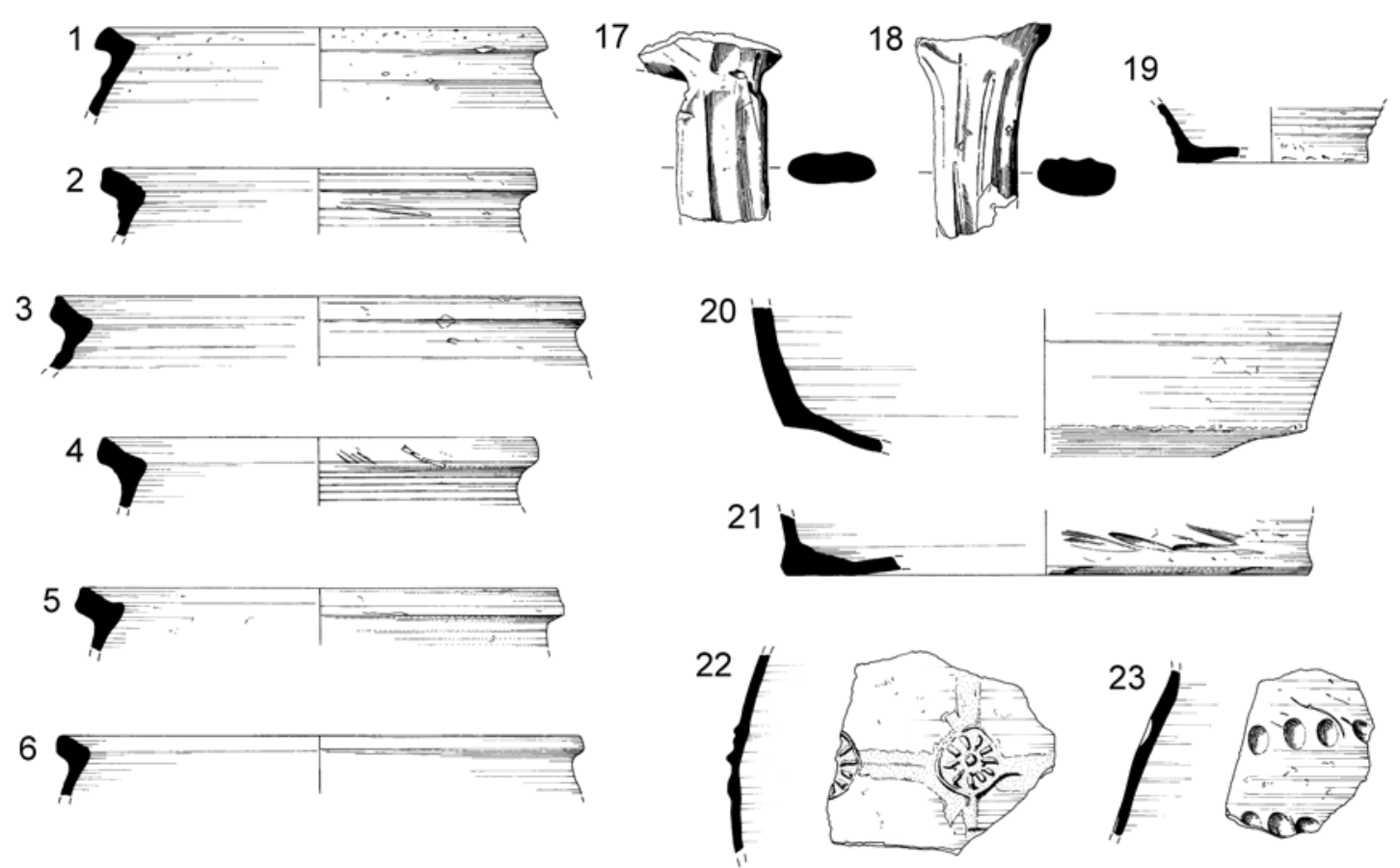

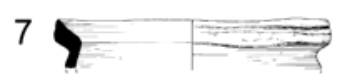

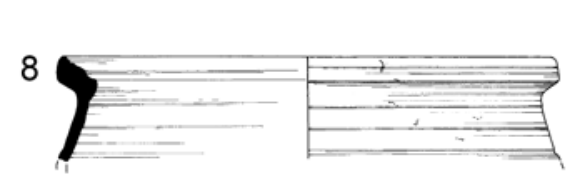

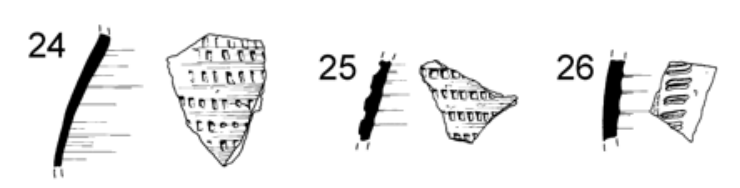
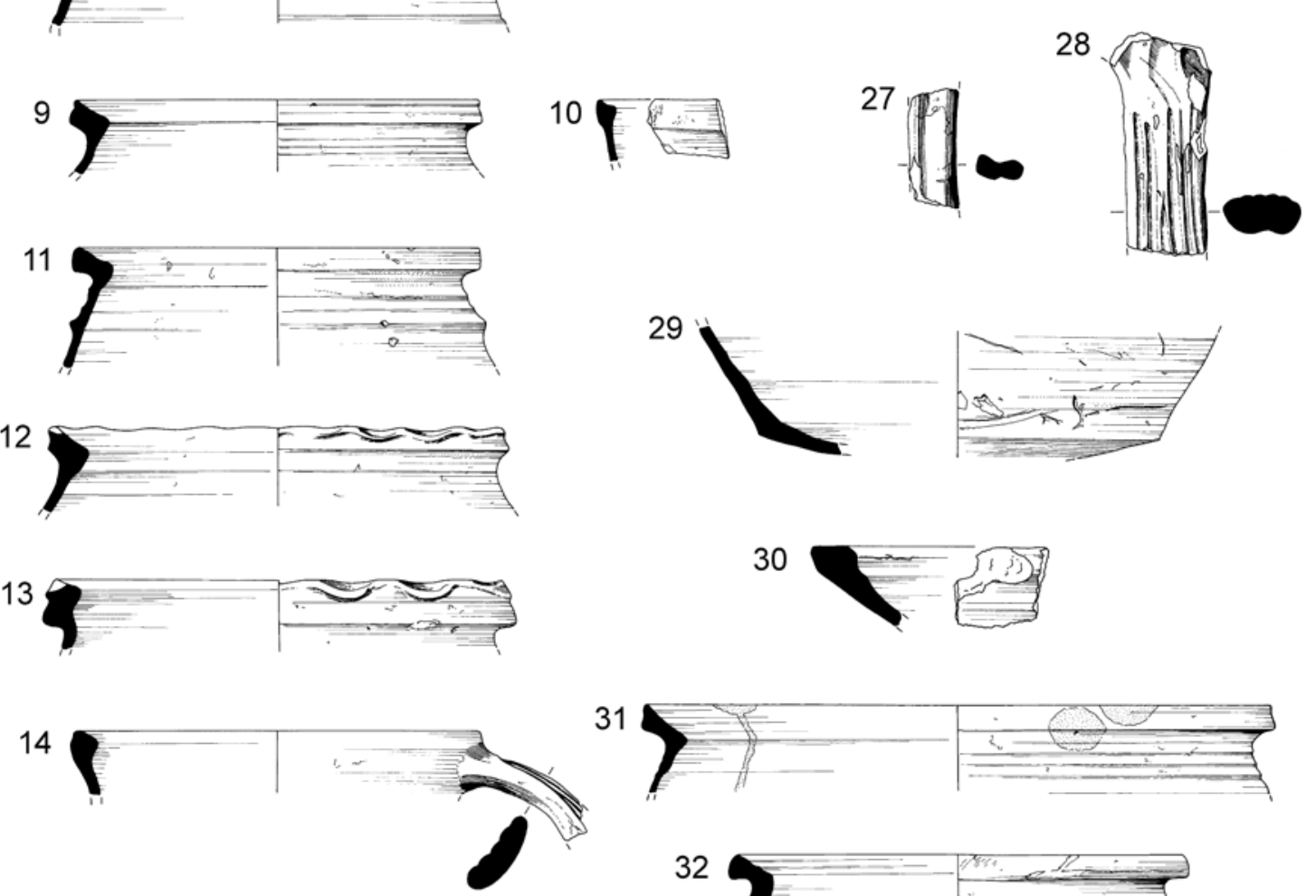

15
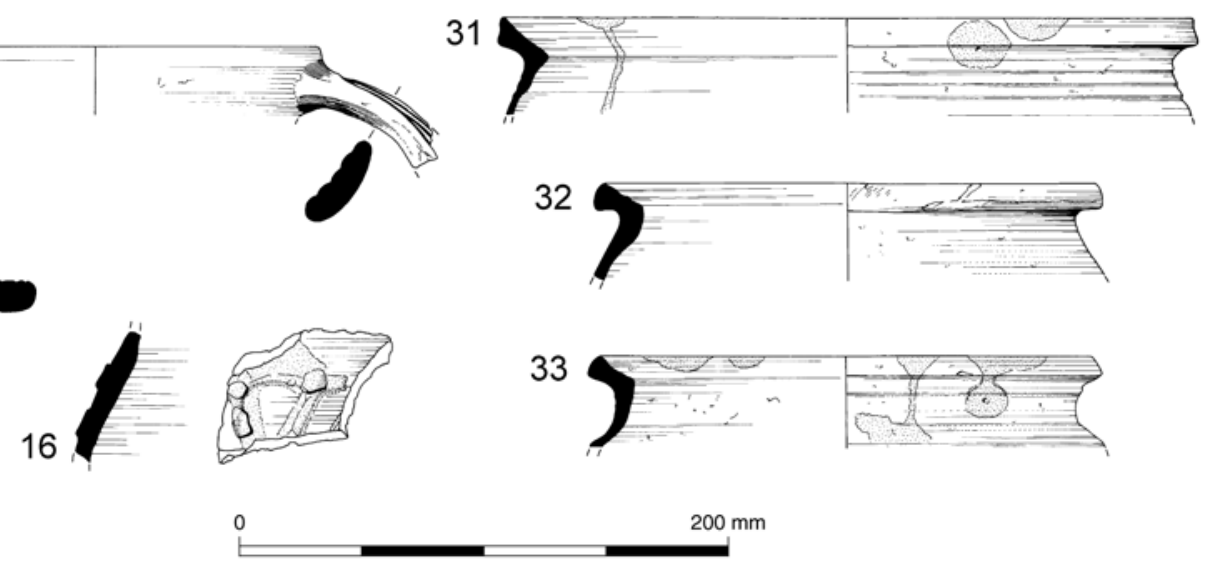

Illus 13 Medieval pottery 

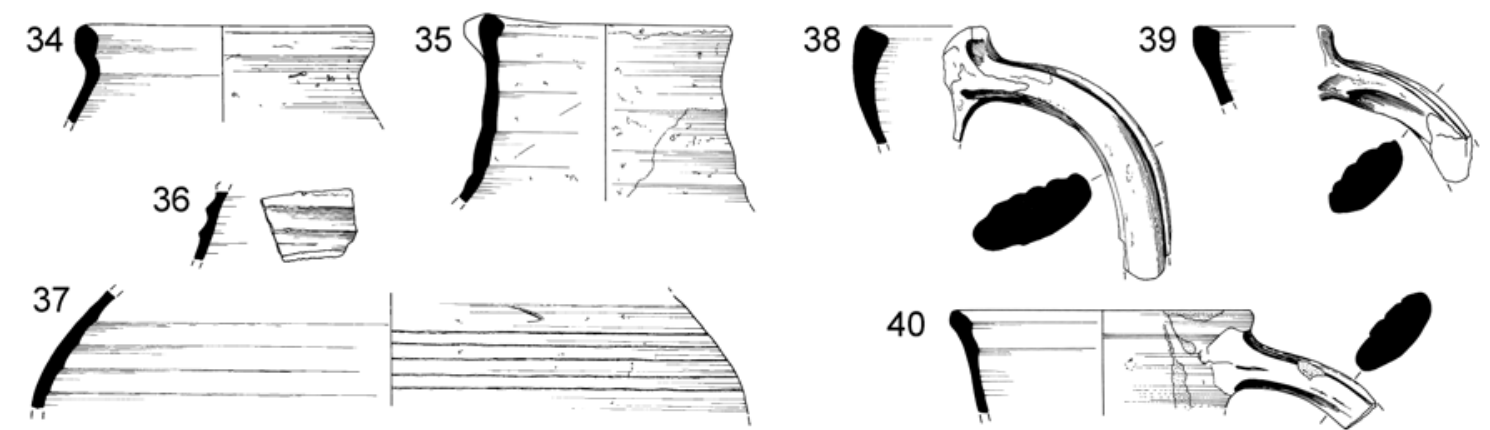

40
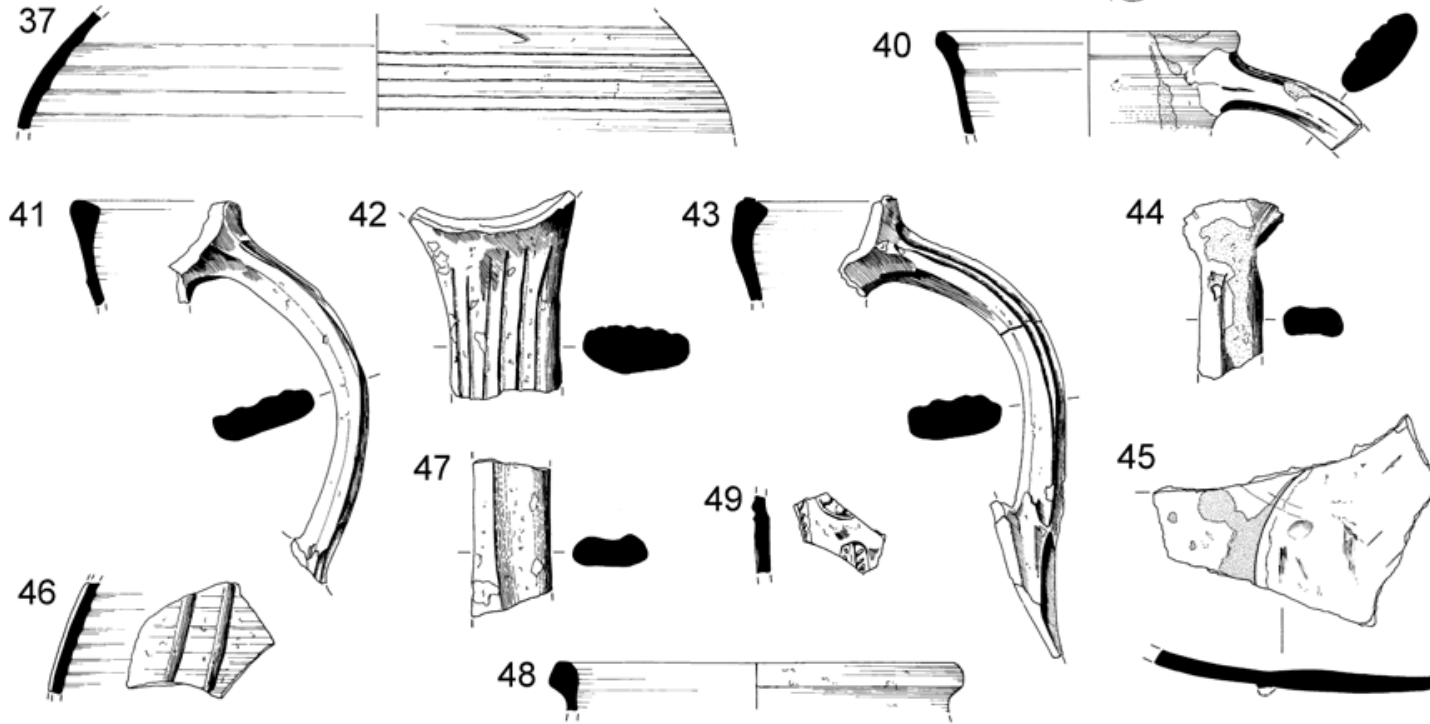

44
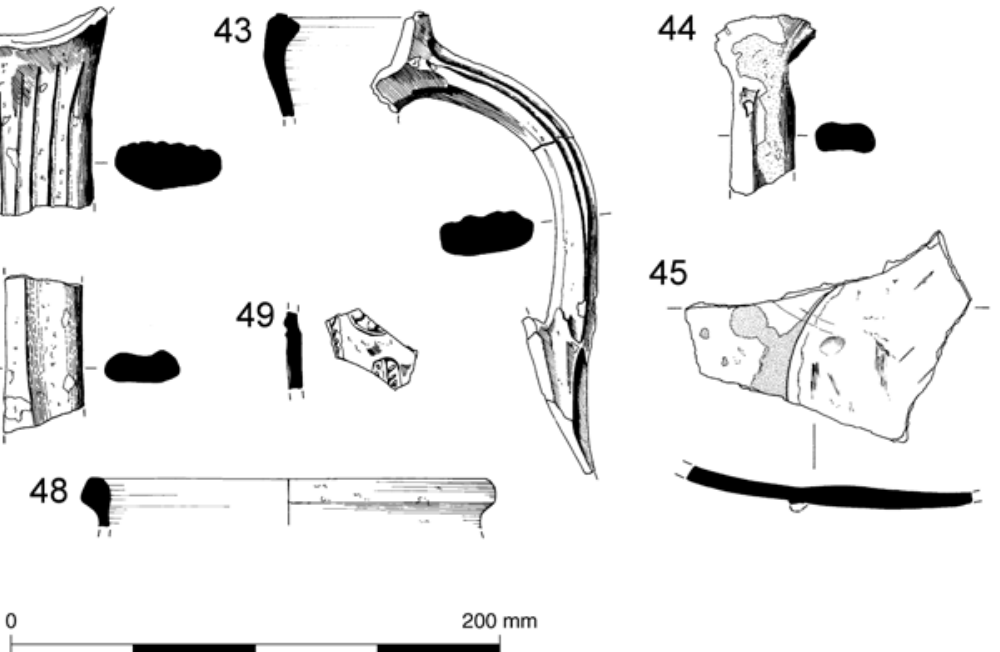

Illus 14 Medieval pottery

30 Rimsherd from dripping pan internally glazed green with patches of external green glaze. F24, topsoil 2401, SF 186.

Scottish White Gritty Ware: Fabric 3

31 Rimsherd from unglazed jar with spots of green glaze on rim. F12, pit fill 1202, SF 059.

32 Rimsherd from unglazed jar with patches of external smoke blackening. F14, upper fill 1402, SF 145.

33 Rimsherd from unglazed jar with spots of green glaze. F19, SF 207.

34 Rimsherd from jar with patches of external green-brown glaze. F19, SF 203.

35 Rim and neck from jug splash-glazed green. F19, hollow 1901, SF 230.

36 Bodysherd from vessel decorated with raised horizontal strips. F7, pit fill 702, SF 054.

37 Joining bodysherds from green-glazed jug decorated with horizontal incised lines. F19, SF 203.

38 Rim and ribbed strap handle from jug splashglazed green. F19, SF 170.

39 Rim and ribbed strap handle from jug splashglazed green. F19, hollow 1901, SF 230.

40 Rim and ribbed strap handle junction from jug with patches of green glaze. F11, gully fill 1102, SF 234.

41 Ribbed strap handle from jug splash-glazed green. F24, topsoil spread 2401.
42 Ribbed strap handle from green-glazed jug. F11, gully fill 1102, SF 234.

43 Ribbed strap handle from green-glazed jug. F24, topsoil spread 2401.

44 Narrow strap handle with splashes of green glaze. F21, SF 013.

45 Basesherd from jug splash-glazed green with stacking mark on base. F24, ditch fill 2404.

Scottish Redware: Fabric 4

46 Bodysherd from green-glazed jug decorated with applied raised vertical strips. F19, upper fill 1904.

47 Narrow strap handle from jug with patches of yellow-green glaze. F19, upper fill 1904.

Unidentified fabric

48 Rimsherd from unglazed jar. F14, upper fill 1402, SF 145.

49 Bodysherd from green-glazed jug decorated with impressed leaves and embossed pellet decoration. F19, SF 203.

\subsubsection{Discussion}

This assemblage is dominated by locally produced fabrics, a common pattern in those areas with 

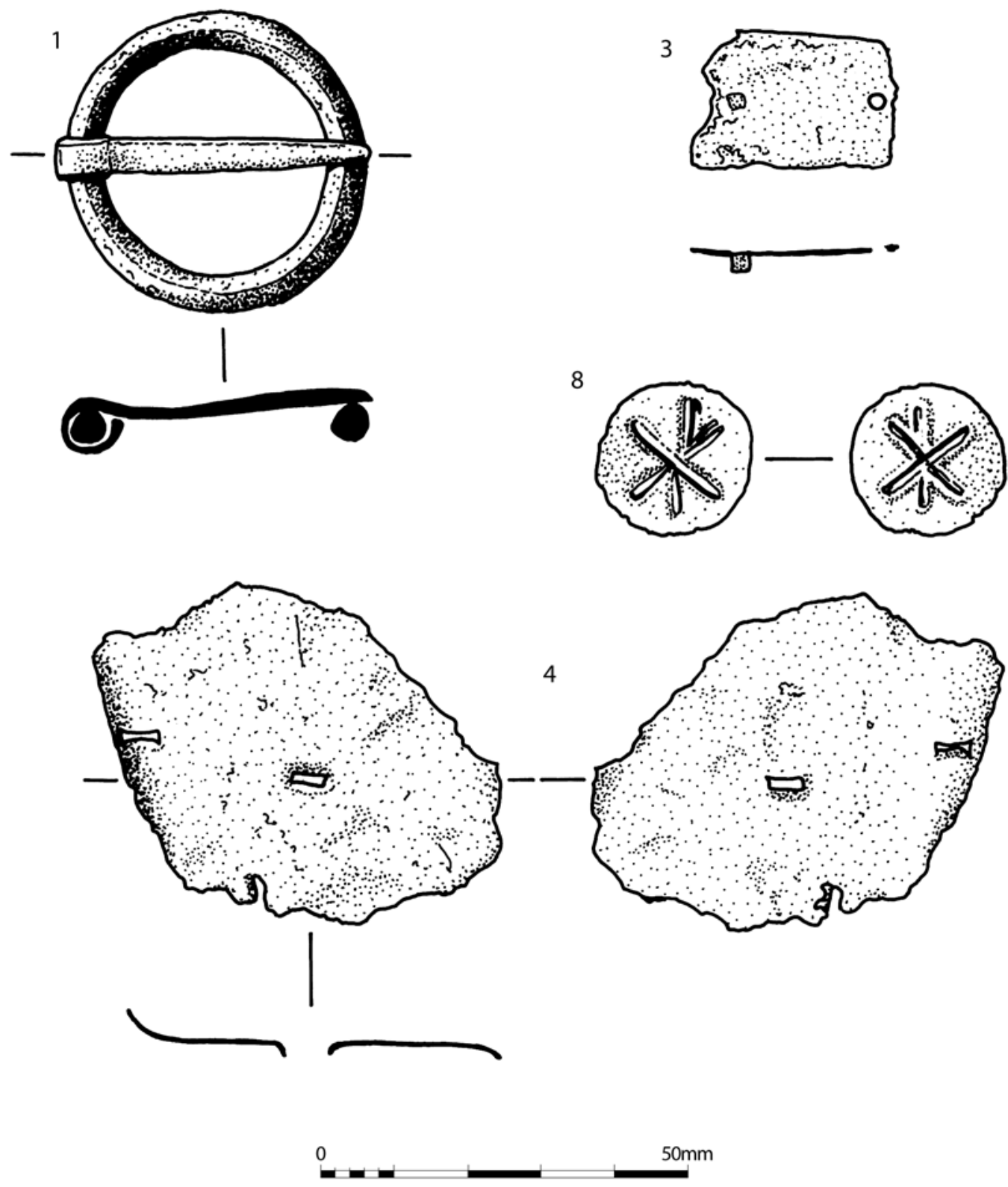

Illus 15 Copper alloy finds

strong White Gritty Ware production. On the face of it the assemblage would seem to be of 13th- or 14thcentury date, although the pitfalls of dating a site only on the evidence of the local wares are readily acknowledged. The presence of a single sherd of Rhenish Stoneware and a dripping pan would fit in with this suggested date.

The local fabrics are visually different from those excavated at the production site of Colstoun, which lies some $20 \mathrm{~km}$ away, and may suggest the presence of a more local production site. The excavations at Hallhill represent a rare example of the excavation of a Scottish rural medieval site which makes this pottery assemblage a very useful addition to the ongoing study of the medieval pottery industry.

\subsection{Copper alloy objects, by Adrian Cox}

The range of copper alloy artefacts recovered represents a number of functional groupings. Of particular interest is the small group of artefacts representing vessel components and vessel repair, recovered from F21 and F24. Further evidence for the recycling of copper alloy came from the surface of F13 in the form of a rolled sheet. Other objects of interest are a group of buckle components, two ferrules and a crudely decorated token.

\subsubsection{Costume fittings (illus 15)}

A complete annular buckle (no. 1) and components 
of two other buckles (nos 2 and 3) were recovered. The annular buckle has a cast frame and a pin made from a tapering strip. Such buckles are distinguished from annular brooches by having a frame uninterrupted by a constriction for the pin (Egan \& Pritchard 1991, 57) and, in this case, the pin is able to move freely around the circumference of the frame. Such buckles were particularly common during the 13th and 14th centuries, although they can date from as late as the mid 15th century. They appear to have been used as belt buckles, either at the waist or the thigh.

Number 2 is from the frame of a buckle of approximately rectangular form, with sides of subrectangular cross-section, incorporating bevelled inner and outer edges on its upper surface. The rear of the frame is flat. The leading edge of the frame incorporates a shallow notch, which may be where the missing pin rested. The buckle form indicated by the surviving fragment suggests a probable 15thcentury or later date. The fragment is most likely to be from a belt or girdle buckle. A probable buckle plate fragment (no. 3) is also probably of medieval date.

\section{Buckle}

External diameter of frame $40 \mathrm{~mm}$; internal diameter $31 \mathrm{~mm}$; max. thickness $5 \mathrm{~mm}$; length of pin 43mm. Complete, annular buckle with a plain, circular frame of slightly faceted, circular cross-section and slightly uneven thickness. The tapering, blunt-tipped pin is made from a single strip and bears file marks at its looped wider end. F19; SF 163.

2 Buckle frame (not illus)

Length $30 \mathrm{~mm}$; width $29 \mathrm{~mm}$; thickness $3 \mathrm{~mm}$. Fragment from the frame of a buckle of nearrectangular outline. F24, topsoil spread 2401; SF 183.

\section{Buckle plate?}

Length $27 \mathrm{~mm}$; max. width $18 \mathrm{~mm}$; thickness of sheet $0.4 \mathrm{~mm}$. Approximately rectangular plate fragment, with two circular rivet holes on its central axis, one of which is occupied by a rivet. F19 surface; SF 173.

\subsubsection{Vessel components (illus 15)}

No. 4 is the largest component of an assemblage of associated fragments representing a repair patch, possibly for a sheet metal vessel. They appear to be of medieval date. The two largest fragments in the group both incorporate punched holes to accommodate sheet metal rivets, and there are 11 much smaller fragments, all with broken edges. It seems likely that all are fragments of a single repair patch which has been subject to post-depositional breakage. Although no traces of the accompanying rivets have survived, these were often fabricated from lozenge-shaped sheets and are sometimes referred to as paperclip rivets.
Examples of patched vessels and repair patches containing such rivets have been excavated at Linlithgow (Stones 1989, 160; illus 101, no. 236L) and Perth (Ford 1995, 961; Cox 1996, 770, illus 19, no. 144).

One of two fragments from the surface of $\mathrm{F} 24$, no. 5 appears to be from the rim of a vessel. It is flattened and distorted, and has been cut (possibly sawn) at one end, and broken at the other. The broken end exhibits possible signs of twisting in order to achieve the break. These fragments are probably of later date than no. 4.

\section{Repair patch}

Length $54 \mathrm{~mm}$; max. width $44 \mathrm{~mm}$; thickness of sheet $0.3 \mathrm{~mm}$. Sheet fragment with roughly broken edges. Two linear rivet holes (length $7 \mathrm{~mm}$ ), with parallel axes, have been punched through the sheet, and traces of a third, set at nearly $90^{\circ}$ to the other two, lie at one of the broken edges. F21, fill 2102; SF 190a.

$5 \quad$ Vessel rim? (not illus)

Length 161mm; max. width $47 \mathrm{~mm}$; thickness $2 \mathrm{~mm}$. Fragment, possibly from the rim of a large vessel, cut at one end and roughly broken at the other. F24 surface; SF 035a.

\subsubsection{Ferrules}

Two ferrules (nos 6 and 7) were recovered. No. 6 probably functioned as the terminal of a wooden accessory such as a pointed cane, or to terminate a broad leather thong. Given its width, the former function appears more likely. Although distorted by crushing, no. 7 probably originally had a circular or oval cross-section and an edge-to-edge seam. It, too, would have been used to terminate a wooden cane or similar object and was secured to it by one, or possibly two, rivets or nails. Both objects are of 17 th-century or earlier date, and may possibly be medieval.

$6 \quad$ Ferrule (not illus)

Length $47 \mathrm{~mm}$; max. width $12 \mathrm{~mm}$; thickness of sheet $0.3 \mathrm{~mm}$. Ferrule of oval cross-section, made from a single sheet with an overlapping seam. The object is open at the wider end, at which part of a circular rivet hole survives, and tapers towards a broken narrower end that may originally have been closed. Corroded. F33, fill 719; SF 117.

7 Ferrule (not illus)

Length $78 \mathrm{~mm}$; max. width $39 \mathrm{~mm}$; thickness of sheet $0.5 \mathrm{~mm}$. Ferrule made from a single sheet. The object tapers slightly from the open end, at which a punched rivet or nail hole and possible traces of another survive, to a closed narrower end. A fragment broken from the closed end is now enclosed within the object. F5; SF 221. 

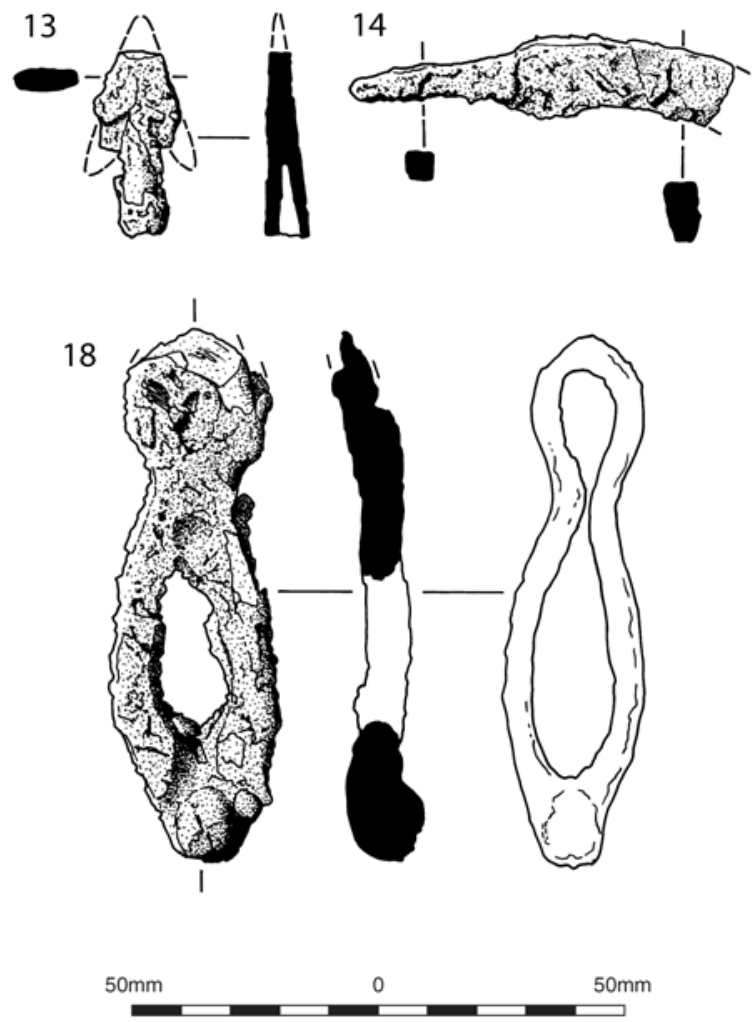

Illus 16 Iron finds

\subsubsection{Miscellaneous (illus 15)}

A circular disc, possibly representing a token (no. 8) came from F5. It bears a crudely executed design of crossed radial lines.

Two loops (nos 9 and 10) were found. In both cases, their mass indicates that they are solid, and made by casting. Both objects show little evidence of wear or corrosion. Considerable force must have been applied to no. 10 to cause it to fracture and become distorted. These appear to be of post-medieval date and may have functioned as links.

An object made from rolled sheet (no. 11) was possibly used to terminate a broad lace or thong. Its broken end may originally have been closed. No. 12 is a rolled sheet, possibly representing an offcut, intended for recycling. This object was associated with two other small fragments, one of which has been tightly folded to produce a double thickness of sheet. Although its original form cannot be determined, it is possible that this may represent part of a vessel rim or a collar around a wooden object.

\section{Token?}

Diameter $21 \mathrm{~mm}$. Circular disc, possibly representing a token, bearing a moulded or impressed design of three raised, radial lines which converge in the centre of the face. F5, gully fill 504; SF 075.

9 Loop (not illus)

External diameter $49 \mathrm{~mm}$; internal diameter
$37 \mathrm{~mm}$; thickness $5 \mathrm{~mm}$. Complete, circular loop of oval cross-section. F24 surface; SF 035.

10 Loop (not illus)

Original external diameter $49 \mathrm{~mm}$; thickness $7 \mathrm{~mm}$. Circular loop, of circular cross-section, broken and distorted. F7 surface; SF 053.

11 Terminal (not illus)

Length $49 \mathrm{~mm}$; diameter $7 \mathrm{~mm}$; thickness of sheet $0.4 \mathrm{~mm}$. Object of distorted circular crosssection, made from a single, rolled sheet with an edge-to-edge seam. Broken at one end. F24 surface; SF 035.

12 Rolled sheet (not illus)

Length 24mm; max. width $15 \mathrm{~mm}$; thickness of sheet $0.5 \mathrm{~mm}$. Plain sheet fragment with one surviving cut edge, rolled so that its ends overlap. F13 surface; SF 026a.

\subsection{Iron objects, by Adrian Cox}

The excavated iron objects are generally in a heavily corroded condition. X-radiography has been used to aid identification and define edges, and, where possible, measurements have been taken directly from the X-ray images.

A barbed and socketed arrowhead (no. 13; illus 16) was recovered from F7. This is heavily corroded, although almost the complete outline survives. With its flat barbs and a central spine, this is most probably a hunting arrowhead or a multi-purpose type that could have been used in either hunting or warfare. The closest identified parallels, including examples from Montgomery Castle (Knight 1993, 226-8) and the excavations at Lurk Lane, Beverley (Goodall 1991, 146), date from around the 13th century, although a slightly later date is also a possibility.

Several blades were recovered. Nos 14 (illus 16) and 15 are certainly from knives and may be of medieval date. The former, recovered from F19, is from a small knife of whittle-tang type. No. 15, from F5, is from a medium-sized knife with a straight back.

No. 16 is a another blade fragment, the curved form of which indicates either a sickle or possibly a long pruning knife. Also found on the surface of F13 is another, smaller, curved object which may also represent a blade. This has a more pronounced curvature than that exhibited by no. 16 and possibly represents a blade from a small sickle. Both objects are very heavily corroded. No. 17 may represent a broad, heavy blade which may have functioned as a cleaver. The rectangular perforation near its terminal would have been used to suspend this implement from a nail. This example may be later than the other blades, possibly of post-medieval date.

Hasps like no. 18 (illus 16) were used in conjunction with staples and padlocks to secure gates, doors, and the lids of chests. One loop would be attached to the door or lid, and the other loop closed around a 


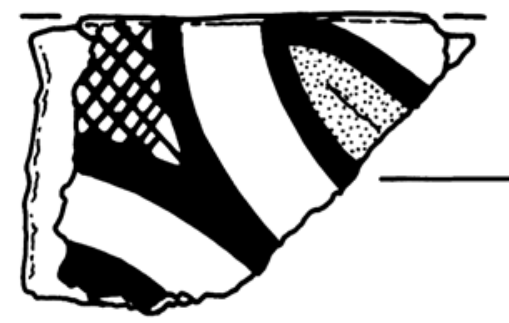

Red brown

\section{Dark brown}

1. Mid brown

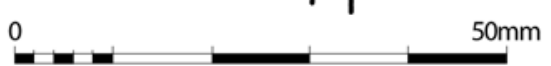

Illus 17 Window glass

staple, to which a padlock could then be attached. Hasps have been excavated at a number of sites, for example at Rattray (Goodall 1993, 182, Fig. 35, no. 93).

No. 19 is a gently curving fragment with a rounded terminal. This may tentatively be identified as part of the arm of a spur, although it is in a heavily corroded and fragmentary condition. It is probably of medieval date.

A socketed object from F11 (no. 20) is probably from a hoe. The surviving fragment represents the socket into which a wooden shaft would have been inserted, and part of the head of the tool. This object appears to be of 17th-century or later date. A hooked terminal (no. 21) may be part of a fitting, or possibly part of a horse bit. No. 22 is probably a machine part and is probably of 19th-century date. It may be from a wheeled device such as a horse-drawn plough, turnip lifter or cultivator. A hooked object (no. 23) is unlikely to have functioned as a hook. More probably, it is part of a larger object incorporating a hooked bar.

\section{Arrowhead}

Length $41 \mathrm{~mm}$; max. width $13 \mathrm{~mm}$; max. diameter of socket $9 \mathrm{~mm}$. Almost complete, barbed and socketed arrowhead, in three conjoining fragments. The ends of both barbs are broken. F7; SF 207b.

14 Knife

Length $77 \mathrm{~mm}$; max. width of blade $12 \mathrm{~mm}$; thickness $c$ 4mm. Almost complete blade and tang from a whittle-tang knife. The blade has a downward-curving back and appears to have had a straight cutting edge. The rectangular cross-sectioned tang is set horizontally, parallel to the blade edge. The tip of the blade is missing, and most of its edge has been lost to corrosion. F19; SF 171.

15 Knife (not illus)

Length $67 \mathrm{~mm}$; max. width $20 \mathrm{~mm}$; thickness $4 \mathrm{~mm}$. Blade fragment, broken at both ends. Heavily corroded. F5; SF 120.

16 Blade (not illus)

Length 142mm; max. width 20mm; max. thickness $4 \mathrm{~mm}$. Knife or sickle blade with a curved back and edge. The blade back curves downwards near the missing tip. The opposite end is also broken. F13 surface; SF 024.

17 Blade? (not illus)

Length 283mm; max. width 46mm; max. thickness (at tang) $14 \mathrm{~mm}$. Possible blade, widening slightly towards the rounded terminal, which has a rectangular perforation. The broken, rectangular cross-sectioned tang is set parallel with the edge rather than the back. F24 surface; SF 200.

18 Hasp

Length $110 \mathrm{~mm}$; max. width $34 \mathrm{~mm}$; max. thickness $16 \mathrm{~mm}$. Complete hasp of elongated figure-ofeight form. Corroded. F7, pit fill 704; SF 053.

19 Spur arm? (not illus)

Length $84 \mathrm{~mm}$; max. width $10 \mathrm{~mm}$; thickness $6 \mathrm{~mm}$. Curving fragment of oval to D-shaped cross-section, possibly representing the arm of a spur. Heavily corroded. F14, fill 1402; SF 113.

20 Hoe fragment (not illus)

Length 192mm; max. width 66mm; max. thickness $35 \mathrm{~mm}$. Tapering, circular cross-sectioned socket and part of the head of a horticultural tool such as a hoe. F11, fill 1104; SF 084.

21 Hooked terminal (not illus).

Length $58 \mathrm{~mm}$; width $14 \mathrm{~mm}$; thickness $8 \mathrm{~mm}$. Hooked terminal made from a rectangular crosssectioned strip, tapering at the hooked end. The opposite end is broken. F7; SF 207a.

22 Machine part (not illus)

Length $217 \mathrm{~mm}$; max. width $29 \mathrm{~mm}$; thickness $8 \mathrm{~mm}$. Curved, rectangular cross-sectioned bar with a curving projection from the concave side. Broken at both ends. F13 surface; SF 024.

23 Hooked bar (not illus)

Length 93mm; max. width $27 \mathrm{~mm}$; thickness $13 \mathrm{~mm}$. Slightly tapering, rectangular crosssectioned, hooked bar, broken at both ends. F15, pit fill 1507; SF 196.

\subsection{Glass, by Adrian Cox}

Four fragments of glass, including two of window glass and two of vessel glass, were excavated. Of chief interest among these is no. 24 (illus 17), a fragment of painted medieval window glass, decorated in a conventionalised grisaille style with cross-hatched 

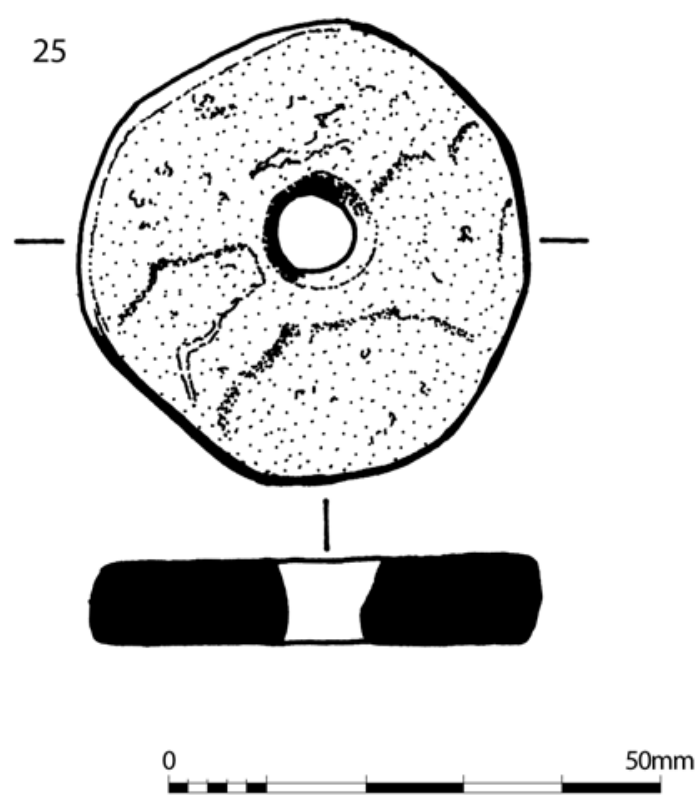
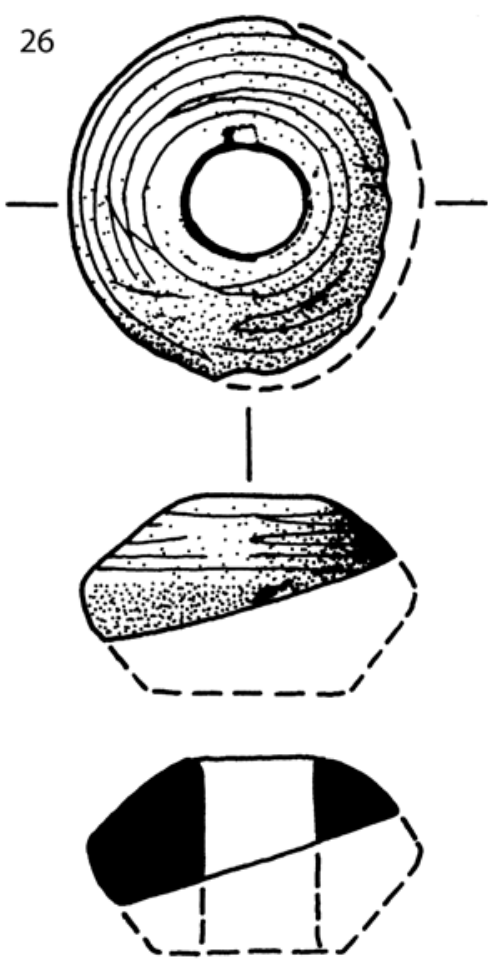

\section{Illus 18 Spindlewhorls}

grounds, possibly of 13 th- or 14th-century date. The recovery of this fragment may indicate the former presence of a high-status building, possibly of an ecclesiastical nature, on or near the site.

A plain fragment of post-medieval window glass was recovered from Trench 2 (unstratified) and two fragments from the bases of 18th- or 19th-century wine bottles came from F7.

\section{Window glass}

Length $45 \mathrm{~mm}$; max. width $29 \mathrm{~mm}$; thickness $4 \mathrm{~mm}$. Fragment of window glass bearing a painted design, probably executed in red, of curving, intersecting bands. One surviving zone between these bands is decorated by fine crosshatching. The background is now almost opaque, and the interior of the fragment is laminated, although a core of clear glass with a slight greenish tint survives. At least one original edge survives. F19; SF 155.

\subsection{Coarse stone, by Adam Jackson}

Sixteen worked stone objects (illus 18-19) were studied and catalogued; the majority were recovered from the three or four possible structures identified during excavation (F13, F14, F19, F22/24). Locally available sedimentary (sandstone) and igneous (dolerite, granite and gneiss) rocks are present in the assemblage; however, most of the finds are of sandstone.

Most finds are of expedient form and comprise small unmodified sandstone boulders with one or more pecked depressions caused by hammering or pounding. These were probably used as anvils or, in some cases, as crude mortars. Cobble tools make up the second-largest category; these comprise, in the main, waterworn stones that have been used as hammers, pounders and/or grinders. A mid-section fragment of a hone or whetstone was also identified. A full catalogue of these items is available in archive.

Curated finds include two spindle whorls, a fragment of a well-worked mortar, a sandstone trough that was discarded during manufacture and a pivot stone. The spindle whorls are of two common forms: a flat-sectioned, straight-sided perforated disc from possible structure F22/24 and a decorated biconical spindle whorl from F13 (nos 25-26, illus 18). Parallels for the former are known from excavations at Threave Castle, Galloway (Good \& Tabraham 1981, 126, no. 193), Springwood Park, Kelso (Dixon 1998, 720) and Perth (Ford 1987, 149 no. 146). Biconical whorls are also common on medieval sites, although many of the closest published parallels are from English sites, eg King's Lynn (Clarke \& Carter 1977, 315) and Northampton (Oakley \& H all 1979, 286-9).

The trough (no. 28, illus 19) recovered from F14 was clearly broken during its manufacture and discarded unfinished. It may have been intended to serve as a water or food trough for livestock rather than as a domestic container. The context of its recovery, face down in the base of 1413 , suggests it may have been reused as building material. The pivot stone (no. 27, illus 19) loosely resembles the base of a rotary quern in that it is roughly circular 

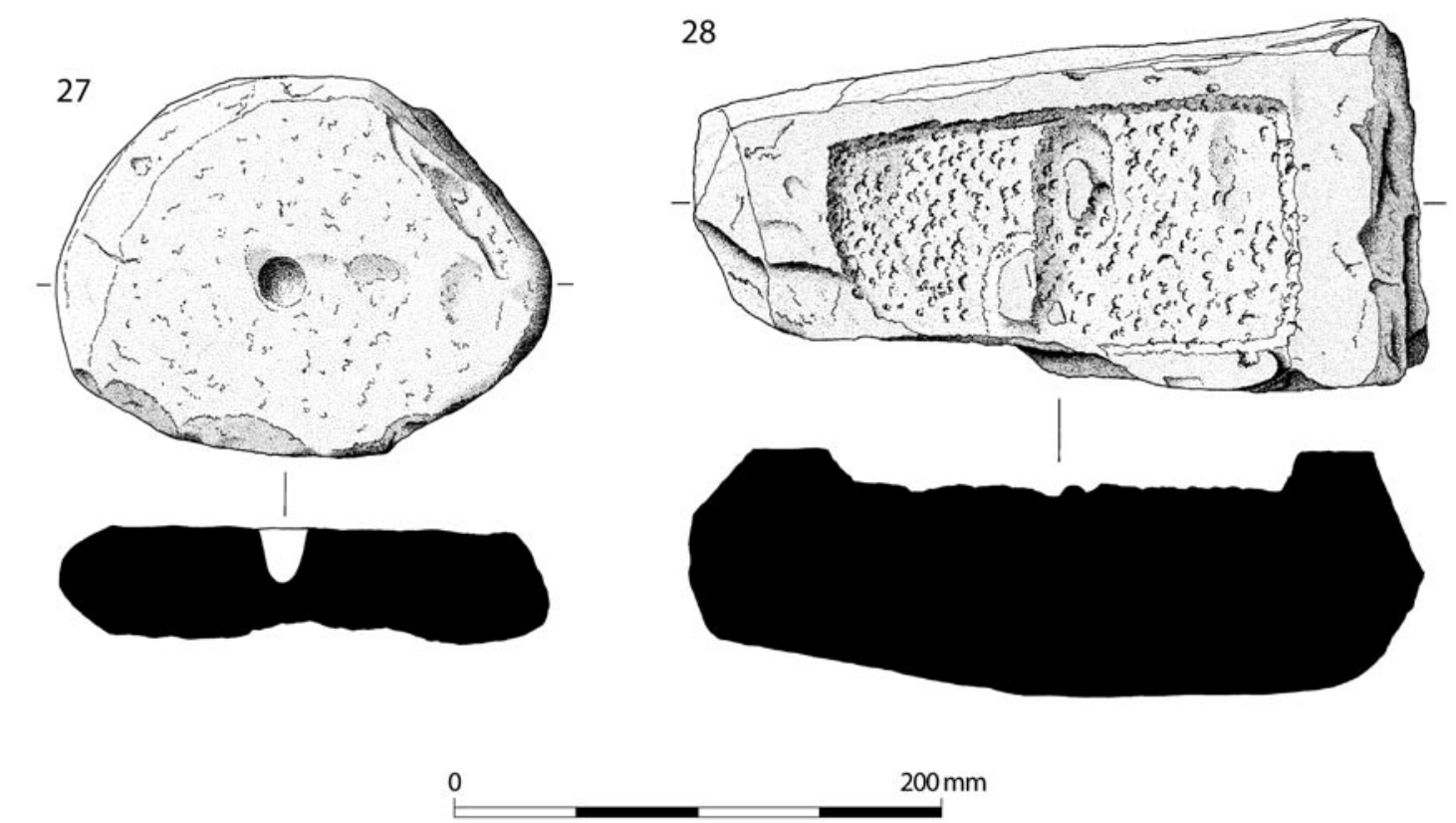

Illus 19 Coarse stone objects

with a flat ground surface and a hole drilled in the centre. However, it is not drilled right through as one might expect and there are no striations to indicate a circular grinding motion.

To conclude, the assemblage is very limited in size and in function. The majority of finds are expedient in nature and cannot be assigned to a particular chronological period. However, the decorated biconical spindle whorl has parallels with finds from other sites of medieval date. The general absence of evidence of domestic milling equipment, with one possible exception mentioned above, is however interesting as it may indicate that domestic hand mills (querns) were prohibited during the period of the site's occupation. The prohibition of domestic querns became widespread in the British Isles from the 12th century onwards as tenants were obliged to take their grain to mills that were owned by the Lord of their Manor (eg Biddle \& Smith 1990).

\section{Perforated disc}

Length $46 \mathrm{~mm}$; width $44 \mathrm{~mm}$; thickness $8 \mathrm{~mm}$; perforation $9 \mathrm{~mm}$. Grey quartz sandstone. Subcircular, flat sectioned. Off-centre perforation drilled from two sides. Sides are straight and flattened by grinding. Flat faces have been partially smoothed. F22; SF 007.

\section{Spindle whorl}

Length $37 \mathrm{~mm}$; width $36 \mathrm{~mm}$; thickness $12 \mathrm{~mm}$; diameter of perforation $11 \mathrm{~mm}$. Steatite. Fragment. Biconical. Central perforation drilled from one side, hence slight narrowing near the top. Some drilling striations can be seen. Faint shallow grooves run vertically through perforation caused by abrasion against spindle. Worn decoration in the form of evenly spaced grooves running around the circumference of the whorl. Damage clearly occurred in antiquity. F13, pit 1315; SF 132.

27 Pivot stone

Length $411 \mathrm{~mm}$;width $325 \mathrm{~mm}$; thickness $96 \mathrm{~mm}$; diameter of depression: 16mm (top), depth $39 \mathrm{~mm}$. Base. Coarse-grained quartz sandstone. Irregular sub-circular plan, with a single ground flat work surface. There is a roughly central Vshaped drilled depression. The depression is smooth-sided, with no visible spiral striations. The rim is worn and rounded. The artefact has been roughly shaped, the sides are pecked and flaked and the uneven base has been crudely flattened. Two parallel grooves near one edge were probably caused by a plough in antiquity. F13, pit fill 1314; SF 177.

\section{Trough waster}

Length $555 \mathrm{~mm}$; width $285 \mathrm{~mm}$; thickness $210 \mathrm{~mm}$; rim 35-40mm; depression $378 \mathrm{~mm}$ long, $210 \mathrm{~mm}$ wide, $35 \mathrm{~mm}$ max. depth. Quartz sandstone. Large, roughly rectangular block. Unfinished trough broken and discarded during manufacture. One face has the beginnings of a rectangular depression. This was created using a hammerstone. The full outline of the vessel interior was defined first, prior to the central area being hammered out. Channels were pecked to pedestal larger chunks of stone that would then be hammered out. One corner and half of one long side is missing. The break occurs at a natural fault in the stone and was probably caused during hammering-out of trough. Base is uneven and approximately one third shows evidence of having been flattened using a hammerstone. F14, 1417; SF 178. 


\subsection{Animal bone, by Catherine Smith}

\subsubsection{Species present}

The Trench 2 assemblage (1235 fragments) was dominated by the bones of domestic livestock: cattle, sheep/goat, horse, pig, dog and possibly cat bones were all present. A small number of red deer bones was also present. Bird species recorded were the domestic fowl (Gallus gallus), possibly cormorant (Phalacrocorax carbo) and oystercatcher (Haematopus ostralegus). A few fragmentary fish bones were also noted but were not identified to species. Table 1 shows the species present by fragment count per feature (including surface finds).

The presence of cattle and sheep/goat bones is to be expected, since the medieval economy depended on hides and wool produced by these two species. However, the relative frequency of horse bones is far higher at Hallhill than is normally the case at urban sites in Scotland. Pig bones are present only in small numbers, as are those of red deer, not unusual in a medieval Scottish context.

Excavations at the multi-period site at Castle Park, Dunbar recovered substantial medieval and post-medieval assemblages (Smith 2000). Table
2 presents percentages of food-forming livestock (cattle, sheep/goat, pig, horse and deer species) from Hallhill alongside comparable figures from Phases 15-20 (medieval) and Phase 21 (post-medieval) at Castle Park. In marked contrast to Castle Park, where cattle were the most numerous species and sheep/goats were less frequent than cattle (based on fragment count), cattle and sheep/goats were present in almost the same numbers at Hallhill (40.3\% and $39.3 \%$ of food-formers). A further contrast is the far greater frequency of horse bones at Hallhill compared with Castle Park, mirrored by the lower frequency of pig bones $(14.4 \%$ and $4.2 \%$ of food-formers, respectively). Deer frequencies were similarly low at both sites.

\subsubsection{Age of animals at death}

Due to the friable nature of the material, few mandibles, used to assess the age of the animals at death, were available in an intact condition. This was particularly true for cattle and pigs; however, ten sheep/goat mandibles survived. Tooth-wear assessment carried out on these jaws indicated ages of death of individual animals, as presented in

Table 1 Total numbers of animal bone

Species:

\begin{tabular}{|c|c|c|c|c|c|c|c|c|c|c|c|c|c|c|c|c|}
\hline Feature & טు & 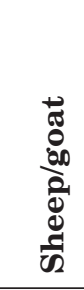 & $\stackrel{\infty}{a}$ & 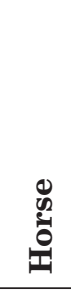 & 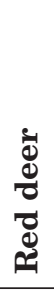 & ڤి & 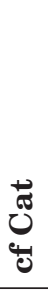 & 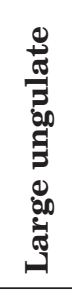 & 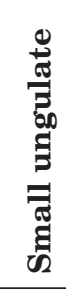 & 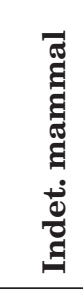 & 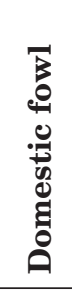 & 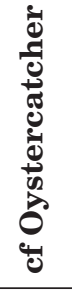 & 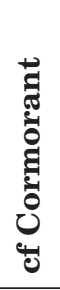 & 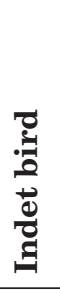 & 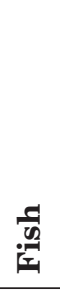 & 胥 \\
\hline F5 & 3 & 2 & & & & & & 1 & & 6 & & & & & & 12 \\
\hline $\mathrm{F} 6$ & 1 & & & 1 & & & & & & & & & & & & 2 \\
\hline F7 & 25 & 12 & & 8 & & & & 8 & 2 & 21 & & & & & & 76 \\
\hline F8 & 1 & 5 & 2 & 4 & & & & 2 & & 14 & & & & & & 28 \\
\hline F10 & 4 & 1 & & 1 & & & & 1 & 1 & 1 & & & & & 1 & 10 \\
\hline F11 & 2 & 2 & & 4 & & & & 9 & 2 & 1 & & & 1 & 1 & & 22 \\
\hline F12 & 1 & & & & & & & & & 2 & & & & & & 3 \\
\hline F13 & 3 & 2 & 1 & 1 & & & & 1 & & 11 & & & & & & 19 \\
\hline F14 & 22 & 22 & 5 & 6 & & & & 7 & 4 & 54 & & & & & & 120 \\
\hline F15 & 11 & 11 & 4 & & & & & 5 & 15 & 30 & 9 & & & 4 & 2 & 91 \\
\hline F18 & & 2 & & & & & & & & & & & & & & 2 \\
\hline F19 & 82 & 88 & 6 & 26 & 9 & 1 & & 23 & 6 & 304 & & 1 & & 1 & & 547 \\
\hline F21 & 7 & 6 & & & & & & & & 15 & & & & & & 28 \\
\hline F 22 & 5 & 12 & & 7 & & 1 & & 2 & & 22 & & & & & & 49 \\
\hline F23 & 1 & & & & & & & & 2 & & & & & & & 3 \\
\hline $\mathrm{F} 24$ & 41 & 40 & 4 & 17 & & & 1 & 17 & 7 & 93 & 1 & & & & & 221 \\
\hline F31 & & & & & & & & & & 2 & & & & & & 2 \\
\hline Total & 209 & 205 & 22 & 75 & 9 & 2 & 1 & 76 & 39 & 576 & 10 & 1 & 1 & 6 & 3 & 1235 \\
\hline
\end{tabular}


Table 2 Numbers and percentages of food-forming mammals at Hallhill Farm and Castle Park, Dunbar

\begin{tabular}{|c|c|c|c|c|c|c|}
\hline \multirow[b]{2}{*}{ Species } & \multicolumn{2}{|c|}{ Hallhill Farm } & \multicolumn{2}{|c|}{$\begin{array}{c}\text { Castle Park, Dunbar } \\
\text { Phases 15-20 (medieval) }\end{array}$} & \multicolumn{2}{|c|}{$\begin{array}{c}\text { Castle Park, Dunbar } \\
\text { Phase } 21 \text { (post-medieval) }\end{array}$} \\
\hline & $n$ & $\%$ & $n$ & $\%$ & $n$ & $\%$ \\
\hline Cattle & 209 & 40.2 & 2493 & 54.2 & 1549 & 60.7 \\
\hline Sheep/goat & 205 & 39.4 & 1371 & 29.8 & 706 & 27.7 \\
\hline Pig & 22 & 4.2 & 582 & 12.7 & 197 & 7.7 \\
\hline Horse & 75 & 14.4 & 106 & 2.3 & 81 & 3.2 \\
\hline Deer sp. & 9 & 1.7 & 46 & 1.0 & 18 & 0.7 \\
\hline Total & 520 & 99.9 & 4598 & 100.0 & 2551 & 100.0 \\
\hline
\end{tabular}

Table 3 Wear stages of sheep/goat mandibles from Hallhill Farm, after Grant (1982) and Payne (1973)

\begin{tabular}{|c|c|c|c|c|c|c|}
\hline \multirow[t]{2}{*}{ Feature } & \multirow[t]{2}{*}{ Context } & \multirow[t]{2}{*}{ SF No. } & \multicolumn{2}{|c|}{ Grant wear stage } & \multirow[t]{2}{*}{ Payne stage } & \multirow{2}{*}{$\begin{array}{c}\text { Age equivalent } \\
\text { (years) }\end{array}$} \\
\hline & & & $\begin{array}{l}\text { Tooth-wear } \\
\text { stage (TWS) }\end{array}$ & $\begin{array}{c}\text { Mandible-wear } \\
\text { stage (MWS) }\end{array}$ & & \\
\hline F8 & 802 & 095 & hg- & $32-37$ & $\mathrm{G}$ (est) & $6-8$ \\
\hline F14 & 1402 & 134 & mhg & 42 & $\mathrm{H}$ & $6-8$ \\
\hline F15 & 1507 & 194 & $\mathrm{gcE}$ & 23 & $\mathrm{D}$ & $1-2$ \\
\hline F19 & 1902 & 164 & $-g f$ & $35-38$ & $\mathrm{~F}$ & $3-4$ \\
\hline F19 & 1902 & 168 & gfC & 24 & $\mathrm{D}$ & $1-2$ \\
\hline F19 & $1902 / 04$ & & $\operatorname{gg}[\mathrm{d}]$ & 33 & $\mathrm{E}$ & $2-3$ \\
\hline F19 & 1904 & 199 & gb- & $20-21$ & $\mathrm{D}$ & $1-2$ \\
\hline F24 & 2401 & 232 & $\operatorname{gg}[\mathrm{d}]$ & 33 (est) & $\mathrm{E}$ (est) & $2-3$ \\
\hline F24 & 2401 & 232 & $-\mathrm{mm}$ & $51-52$ & I & $8-10$ \\
\hline $\mathrm{F} 24$ & 2404 & 224 & hgg & 37 & $\mathrm{G}$ & $4-6$ \\
\hline
\end{tabular}

Table 4 Numbers and percentages of cattle and sheep/goat long bones, by age category

\begin{tabular}{lrrrr}
\hline \multirow{2}{*}{ Age category } & \multicolumn{2}{c}{ Cattle } & \multicolumn{2}{c}{ Sheep/goat } \\
& $\boldsymbol{n}$ & $\%$ & $\boldsymbol{n}$ & $\boldsymbol{\%}$ \\
\hline $\mathrm{J}$ & & & 6 & 31.6 \\
$\mathrm{~J} / \mathrm{I}$ & 8 & 27.6 & 1 & 5.3 \\
$\mathrm{I}$ & 1 & 3.4 & 2 & 10.5 \\
$\mathrm{I} / \mathrm{A}$ & 14 & 48.3 & 5 & 26.3 \\
$\mathrm{~A}$ & 6 & 20.7 & 5 & 26.3 \\
Total & $\mathbf{2 9}$ & $\mathbf{1 0 0 . 0}$ & $\mathbf{1 9}$ & $\mathbf{1 0 0 . 0}$ \\
\hline
\end{tabular}

Note: $\mathrm{J}=$ juvenile, $\mathrm{J} / \mathrm{I}=$ juvenile or immature, $\mathrm{I}=$ immature, $\mathrm{I} / \mathrm{A}$ $=$ immature or adult, $\mathrm{A}=$ adult

Table 3. Three animals died or were killed between the ages of one and two years (based on modern animals), but at least one animal lived to an age between eight and ten years. Although this is a very small sample number, the importance of husbanding the animals to a fairly advanced age indicates the significance of wool production, as has been noted at Castle Park, Dunbar (ibid, 219).

Long bone epiphyseal fusion evidence was also collected for the Hallhill bones. Although generally recognised to be less reliable than tooth-wear analysis, fusion states also provide a guide to age at death. Those cattle and sheep/goat bones in which the articular ends (epiphyses) were present were therefore assessed. The results, for what proved to be rather small samples, are shown in Table 4. It can be seen a number of cattle and sheep/goats died or were killed when young, although there was good survival into adulthood for other individuals. Notably, the epiphyseal fusion results for sheep/ goat are in good agreement with the mandibular evidence.

The evidence for other species was rather sparse. However, one pig mandible (F14, fill 1402) came from an animal estimated to have died between the ages of eight and ten months. The pig long bones came mainly from juvenile or immature animals.

All horse long bones came from adults with the exception of two unfused examples (a distal metatarsal and a calcaneum) which represent a juvenile or immature individual (fill 1402).

At least one young red deer was also present in F19 (fill 1902) as shown by the presence of an unfused distal metapodial, although all other deer bones probably came from adults. Two conjoin- 
ing fragments of frontal bone from a dog skull were unfused, indicating they came from a young animal.

\subsubsection{Size and appearance of animals}

Anatomical measurements were made on suitably intact bones of cattle, sheep/goat, pig, horse, red deer and domestic fowl. A full list is available in archive. The domestic livestock seem to have been of the small stature typical of animals in Scotland prior to the era of agricultural improvement. Comparison with data from medieval and post-medieval phases at Castle Park, Dunbar indicates a very good correlation with the animals recorded there (ibid, 238-77). One cattle metatarsal from a surface layer in F8 was estimated to have come from a beast of about $111 \mathrm{~cm}$ at the withers (shoulders). This falls well within the range of withers heights recorded at Castle Park, Dunbar, where, for example, the mean for Phase 14 (medieval) was $110.6 \mathrm{~cm}$ (ibid, 209) and indicates the bone was probably from a disturbed medieval or post-medieval context, rather than from a modern deposit.

Although complete sheep/goat bones were present, available measurements indicate that the sheep were also of the small stature associated with the medieval period. Two horn core fragments indicate that the sheep were horned: one in F33 (fill 716) was large, robust and probably from a ram. Another fragmentary example was present in a surface layer in F9 (NW corner).

Several of the horse bones were intact and provided good evidence of the stature of the live animals. Five complete long bones (a humerus, three radii and a metatarsal from F10, F6 and F14) were estimated to come from animals standing between $126.9 \mathrm{~cm}$ and $129.5 \mathrm{~cm}$ at the shoulder, based on Kieswalter's factors (Ambros \& Müller 1980, 30). Traditionally, horses in Britain today are measured in 'hands', where one hand is equivalent to four inches. This means that the Hallhill horses were between 12:2 and 12:3 hands height. Since all horses under the height of 14:2 hands can be described as ponies, the Hallhill animals may be seen to be of relatively small stature. A survey of horses from Scottish medieval urban sites showed that only bones from ponies between 12 hands and 14:2 hands height were present; no larger animals have been recovered from urban sites as far afield as Inverness, Aberdeen, Elgin and Perth (Smith 1998, 870-2). The ponies from Hallhill are therefore typical of this period in Scotland. It is notable however, that a later medieval phase at Castle Park contained a single bone from an animal of $173 \mathrm{~cm}$ or 17 hands height, but this is very unusual (Smith 2000, 216).

The few red deer bones recovered indicate robust animals. Unlike their domesticated cousins, red deer did not increase in size between the medieval and the modern periods. Rather, they show a marked decrease in size, due to the environmental pressures of agriculture, forestry and 19th-century hunting practices.

\subsubsection{Butchery}

The animal bones were butchered using the tools typical of the medieval and post-medieval periods. In other words, cleavers or axes were used to disjoint carcasses and split bones. No saws, a fairly modern innovation, were used. Knife cuts were evident on some of the bones of cattle, sheep/goat, pig, red deer and horse. In the case of horse, these knife cuts, as well as chop marks made by cleavers, indicate either the consumption of horse meat, as food for humans or dogs, or skinning of the carcass. Where the bones have been chopped, however, it seems that the meat must have been used.

Evidence of removal of sheep horn cores from the frontal bone of the skull was noted in two examples. Presumably the horny outer sheaths were used in artefact manufacture, while the cores, having no further use, were discarded.

\subsubsection{Discussion}

The faunal assemblage indicates that domestic livestock, particularly cattle, sheep/goats and horses were kept and killed for food by the inhabitants of the site. Wool also seems to have been important to the local economy, as shown by the presence of mandibles from older sheep. The small stature of the animals, together with the style of butchery, indicates a medieval or post-medieval date for the bones.

The presence of so many horse bones on the site is unusual, and although some of the bones may indicate the burial of natural casualties, or those culled because of disease, the presence of butchery marks on some of the horse bones indicates that the animals were at least relieved of their hides before burial and in some cases the meat, too, was stripped off. The horse bones do not seem to represent discrete burials; rather the bones are scattered throughout the majority of the features and all come from pit or gully fills, in association with other domestic refuse, again indicative of use of the meat and hides after death. At Castle Park, Dunbar, there was also strong evidence to show that horses were not simply buried on death, but were used as a food source throughout the life of the site, from the Iron Age to the postmedieval period (Smith 2000, 231-3).

Wild animals were also hunted for their meat, particularly red deer, but sea birds were also potential suppliers of fat and protein. A bone, probably from a cormorant, was probably deliberately brought to Hallhill, presumably originating from the shores of the Forth or its islands such as the Bass Rock or Fidra. The oystercatcher may also have served as food, but was more likely to have been trapped at its breeding grounds inland. Coastal communities 
in Scotland have exploited sea birds as food since prehistoric times; bones of various species including cormorant, oystercatcher, gulls and birds of the auk family were all found at Castle Park (ibid, 202). As at Castle Park, however, sea birds and wild mammals served only to supplement the diet at Hallhill, the main meat sources being cattle, sheep/goats, pigs and horses.

\subsection{Marine shell remains, by Ruby Ceron-Carrasco}

The marine shell remains derived from three contexts, F8 (802), F14 (1427) and F24 (2404), of which bulk samples were sieved to retrieve organic remains or ecofacts.

The results of the marine shell identification are given in Table 5 with the summary of species represented per context. Only gastropods were present and their frequency was estimated by counting the shell apices. The marine shell species were quantified to provide an idea of main species representation; when too fragmented, the shells were quantified in terms of their relative frequency within each sample. This frequency was recorded as:

\footnotetext{
$* *=$ Present i.e. present in low quantities compared to main species $(<10)$.

$* * *=$ Common i.e. present in large quantities similar to other species within a sample.
}

The most common species present was the edible periwinkle (Littorina littorea) also known as 'wulk' on the east coast of Scotland. Periwinkles are found on rocks, stones and seaweed on the middle and lower shores. Its shell may be up to $2.5 \mathrm{~cm}$ high. Although it has been demonstrated that a variety of environmental factors can influence the shells of certain other molluscs, studies done by Hylleberg \& Christensen (1977) on edible periwinkles suggest that there are no significant allometric differences in Littorina littorea shells attributable to their recovery from different environments. The limpet Patella vulgata, was also common and it is also a species found throughout the Scottish coast on all rocky shores and in shallow waters (Branch 1985; Campbell 1989). A very small amount of rough-periwinkle (Littorina saxatilis) was also recovered and it is assumed that these were accidentally gathered with the larger species of the edible periwinkles.

From early historical accounts it seems obvious that shellfish of various types were used as food in
Scotland and there is considerable regional variation in the uses as food. Furthermore, shellfish have also been traditionally used as fishing bait and fishing techniques have depended greatly not only on the availability of fish species and equipment but also largely on the seasonal variation in the type of bait (Fenton 1984). The two main species present in the Hallhill marine shell assemblage were periwinkles and limpets, which have been used as food and as fishing bait in Scotland (as well as mussel, although this was not present here).

The Burgh of Dunbar has had a long history of fishing, the construction of its harbour dating to the medieval period and, from at least the 18th century, it ranked as the main herring port in Scotland. Apart from herring fishing, Dunbar was also important for its 'white-fishing', ie fishing of cod fishes (cod, whiting, haddock, ling, etc) as well as flatfishes (sole, plaice, etc) and skate; for these, baited lines would have been required. Early historical records show that a variety of baits were used depending on local availability and on the fish being sought (Coull 1996).

In conclusion, as most of the specimens of shellfish present were from small juvenile specimens, it is assumed that these are the remains of shellfish that were used as fishing bait.

\subsection{Dating evidence}

As noted above, no palaeobotanical analysis was carried out on the samples from this site due to the heavily bioturbated nature of the soil. As a result, there was no programme of radiocarbon dating. This, together with the lack of any clear stratigraphic relationships, means that all dating is based on the artefactual evidence. Most features produced at least one or two sherds of medieval pottery which has been dated to the 13th/14th centuries (Hall, above). The few metal finds which could be dated were also largely of medieval date (Cox, above). Some post-medieval finds were also recovered, but these were generally surface or upper fill finds and were probably intrusive from the topsoil. It is therefore suggested that the majority of features on this site probably relate to a single phase of occupation in the 13 th -14 th centuries.

\subsection{Distribution of finds}

The largest groups of finds from the site were marine shell, bone and pottery. The large quantities of shell

Table 5 The marine shell remains

\begin{tabular}{lccc}
\hline \multicolumn{1}{c}{ Species } & Context 802 & Context 1427 & Context 2404 \\
\hline Periwinkle (Littorena littorea) & $310(* * *)$ & $250(* *)$ & $260(* *)$ \\
Limpet (Patella vulgata) & $710(* * *)$ & $120(* * *)$ & $240(* * *)$ \\
Rough periwinkle (Littorina saxatilis) & & & 12 \\
\hline
\end{tabular}


were recovered from three contexts in F8, F14 and F24. Bone and pottery were both distributed across most features on the site, with particular concentrations in F7, F14, F15, F19 and F24. Finds were recovered both within negative features and on their surfaces, the latter often forming the greater proportion of the assemblage from each feature. The large quantities of finds recovered from the gullies of F19 and F7 are most likely to relate to the use of these features and may represent the middening of domestic waste during occupation. Pits were probably also used for the disposal of rubbish, and F15, for example, may have been in use during the life of structure F14. The fill of the latter, however, is more likely to relate to post-abandonment dumping and the same may be true of surface deposits over the other features. Generally the finds are likely to have been deposited close to their areas of use, although the large group of material from the fill of F14 may reflect its use as a convenient dump site once the superstructure had gone, rather than representing material which was used in the structure itself. Nevertheless, pottery from underlying features was of medieval date and the structure is assumed to have been short-lived but contemporary with the rest of the site. 


\section{DISCUSSION (TRENCH 2)}

Very few rural medieval settlements in Lowland Scotland have been excavated in recent years. Springwood near Kelso (Dixon 1998) and Eldbotle, Dirleton (Morrison et al 2008) had substantially better preserved structures than Hallhill, whilst Gogar had no structural features (Morrison et al 2009). Although later agricultural activity had removed much of the structural evidence from Hallhill, the excavation revealed some similarities with the buildings identified at the other sites, but also some major differences.

\subsection{The 'sunken-floored' structures: a possible workshop?}

The two irregular 'sunken-floored buildings', F13 and F14, have no close parallels in medieval Scotland so far. There is a possibility that the sunken nature of the floor was simply a result of erosion of a bare earth surface over a number of years, rather than being a deliberate attempt to create a sunken floor as seen in the sunken-featured buildings of Early Saxon England or the cellared buildings of the Late Saxon period.

F14 is the most convincing structure of the two, having three partial or complete straight 'walls'. The central part of this feature had a relatively level floor, but the varying angles of slope at its edges indicate that the sunken area was never revetted with timber or stone, at least not in the surviving part. There is, however, a slight step in the profile of the cut along the straight sides which could originally have held footings for a timber structure or wall-lining. The step appears insufficiently wide to form a base for a turf-walled structure, although this does not preclude the existence of such a structure outside the edges of the pit at a higher ground level which is now lost. Two small stakeholes in the southwest corner and a central post-hole in the northern side were the only structural evidence remaining, and these could perhaps have been used to support horizontal plank walling at a higher level. Although a few stones were located around its edges, there is no real evidence of any stone footings for the superstructure, nor is it apparent that any were padstones for a cruck roof.

The nature of $\mathrm{F} 14$, with only three straight sides, may suggest that it was simply cut into the terrace to provide a level floor. Perhaps the northern side was even open to the elements, if not just lost through truncation. The north-eastern corner had certainly been removed by modern disturbance. At the west side of the north-west corner, a shallow hollow, pit 1413 , may represent the location of a side entrance and could have been produced simply by erosion. The two stones placed across it would then have formed a threshold, although their height would appear to have made them a hindrance to entry rather than a help. The stakeholes lining the north side of this hollow might then be interpreted as supports for a handrail. Alternatively, they could represent the line of the north wall, if it existed.

An irregular oval pit cut the floor at the west end (1424) but produced no finds or evidence of function. The fill of pit 1424 was the same as the overlying abandonment fill of the structure, suggesting that it was open during the life of the structure. It may be a product of erosion from human activity within the structure. A burnt patch in the centre of the floor suggested that the building was heated, but the evidence does not suggest a hearth and perhaps the patch was caused by hot ashes from a brazier. These features suggest that it had an earthen floor, which has been postulated for other types of sunken-floored structure in Scotland, such as the earlier oval or circular examples at Easter Kinnear, Fife (Driscoll 1997) and Ratho (Smith 1998).

Like Saxon sunken-featured buildings in England, the structure appears to have been used as a rubbish pit after demolition, containing a large quantity of pottery and other artefacts within its fill. These, therefore, do not necessarily belong to its use phase and may be related to another structure or structures on the site. However, a few sherds of pottery were also collected from pits in the base of the structure and these were broadly contemporary with the pottery from elsewhere on the site. Even if F14 was abandoned whilst other structures were still in use, it is unlikely to have been constructed earlier than the rest of the settlement.

F13 was considerably shallower than F14 and contained several features. It had no definite structural edges, but stones present in the topsoil and overlying the abandonment layer could represent plough-dragged, heavily truncated footings. The lack of structural edges suggests any stone or turf wall must have been built away from the edges of the scoop. Again, this shallow hollow may have been caused by erosion if the features it contained were in constant use. Patches of gravel may represent attempts to metal the surface. It might then be interpreted as a work area with an adjacent workshop (F14). A possible (?earlier) parallel for this would be two sub-rectangular hollow defined features discovered at Birnie, Moray, which appeared to be associated with a smithy (Hunter 2003). Whether it was ever walled and/or roofed is uncertain from the available evidence.

The two features together appear to represent an 
industrial or craft area, but exactly what function they had is uncertain. If the oval pit 1426, containing a large quantity of shells, was incorporated into structure F14, it is tempting to suggest that the structure was used for food processing and cooking. Also, pit 1315 produced a significant quantity of coal. This was readily available from seams on the east coast, but was not the fuel of choice for domestic use in the medieval period, being preferred for smithing and other industrial processes. No slag was recovered at Hallhill however, so smithing seems an unlikely use here. Other crafts which could have been carried out in a workshop may be represented in a few of the finds from F13. A spindle whorl might suggest that spinning took place. Two possible mortars were deposited in one pit, and a hammerstone or pounder was found in the fill of F14, so grinding of grain was probably being carried out. However, all of these objects may have been brought from elsewhere rather than used in the features. The mortars were deposited with other stones, including a pivot stone, in the top of a large pit in F13 and may have been used simply to level an inconvenient hollow caused by subsidence of an earlier pit. The hammerstone might have been dumped during rubbish disposal after the life of F14, as discussed above.

The pits to the east side of F14 may have been used for rubbish deposition during the life of the structure. Double pit F15 in particular produced a large quantity (115 sherds) of pottery and some animal bone (91 fragments). The peaty nature of the lower fills of one pit might indicate the deposition of cess.

\subsection{The enclosure F19}

The interpretation of F19 as an enclosure around a structure rests on limited evidence which consists of the presence of a T-shaped fragment of stone footing in its south-east corner, and a large possible firepit or hearth at the east end of the gully-defined enclosure. Given that the footing appears to extend to the east, there is a possibility that its presence within the enclosure was fortuitous and that either it was later and extended beyond the limits of the shallow ditch to the east, or that it was earlier and the footing was removed by the ditch. The severe truncation of the site means that either of these interpretations is feasible.

However, as noted above, there is some suggestion that the shallow gullies which make up the enclosure were dug to provide earth with which to form a level platform of which nothing survives as a result of truncation, as well as for drainage. If so, it is not the gullies themselves which are important, but the area they enclosed. They were clearly too shallow to form any useful feature in their own right. A possible parallel for this method of construction can be seen at Greod, Sanday (Wickham-Jones 2001, pl 7), where stone footings appear to sit on rectilinear house platforms with possible shallow gullies at either side. The buildings there had gaps between them, but these were not delineated by gullies and the divisions between them would not be visible if the shallow footings had been lost. Stonefooted structures on platforms were also excavated at the upland farmstead of Dowglen in Annandale (Cannell 1985; Dixon 2002, 29), although these appear to have been built at right-angles to the terrace.

Based on evidence from Springwood (Dixon 1998), the stone-footed structures might have been approximately $10 \mathrm{~m}$ in length and two or perhaps three could have been fitted lengthways along the putative platform. There is possible evidence for further wall footings in the wide gully forming the central southern part of F19, although the stones here appeared to be resting on top of the fill of a short length of ditch which cut the base of the gully. It is an unlikely candidate for a foundation trench, so the function of this ditch is uncertain, as is the position of the wall. A possible suggestion is that the stones were moved here through ploughing or subsidence, but even if this were the case, the ditch is difficult to explain. If there was only one house on the platform, perhaps the other end functioned as an enclosed garden or yard.

F19 produced the largest groups of pottery and animal bone from any feature on the site, a total of 310 sherds and 547 fragments respectively. This is suggestive of a build-up of midden deposits in the open gullies, the fill of which also showed layering of marine shells at the widest point. This section of gully was closest to F14 and it may have been open during the life of that structure, perhaps allowing for shell waste to be deposited from there. The fragment of painted medieval window glass found in this feature would be an unusual object on most medieval rural sites and must have come from a high status or ecclesiastical building. Its condition is not suggestive of significant movement following deposition, so it is unlikely to be intrusive from the ploughsoil, however there is no other suggestion of a high-status building here. Perhaps it was deliberately brought to site as a curiosity or a talisman.

\subsection{Structure F24}

The collapsed stone footings of a possible rectangular building were identified following the topsoil strip. These were only one course deep and excavation revealed that they sat within the fill of an apparent hollow in the subsoil. A ditch on the south side of the hollow curved around to enter a deep pit, possibly a soakaway, which may indicate that the ditch was a drain for the structure. Unlike those at Springwood and Eldbotle, the feature was not stonelined or capped. If the ditch curved around to avoid the wall of the structure, it is possible that the latter extended to the west and was up to $9 \mathrm{~m}$ in length. Perhaps the footings survived in this area simply because they were built on an infilled hollow which 
later slumped, leaving them at a slightly greater depth below the ploughsoil and less susceptible to damage. It is possible that some of the stones in this area were the remains of paving rather than a footing, in which case they might perhaps represent another industrial or craft area.

This area produced 219 fragments of animal bone and 113 sherds of pottery, as well as fragments of a copper alloy buckle, a vessel rim, a possible iron blade and a grinder stone. A plain perforated disc spindle whorl and a whetstone came from the possible soakaway pit. This may simply be an assemblage of domestic waste deposited after the structure went out of use.

\subsection{Feature F7/F5}

The shallow gullies forming F5 and F7 were similar in appearance and character to each other. Their purpose is enigmatic; while their common alignment with F19 and F24 invites comparison, F5 and F7 appear to comprise fairly simple gullies and do not obviously form part of a ditch-defined linear feature. The short right-angled gully at the end of F5 and the longer gully F11 could suggest the termini of an enclosure like F19. Equally, the large pits within F7 could represent the footings of a timber building, but if so this would have been a fairly substantial structure and the opposing wall should have been visible despite the greater degree of truncation seen to the north side of these structures. Several postmedieval finds were recovered from the fills of this feature, but given the degree of disturbance it is possible that they were intrusive from the ploughsoil. The shared alignment of three ditches, F8, F20 and F23 hints at these long linear features forming the edge of a wider agricultural or plot boundary system close to the more permanent centres of human activity (F13, F14, F19, F24). 


\section{$7 \quad$ CONCLUSIONS}

The features excavated at Hallhill are difficult to relate to previously excavated rural settlements, having little in common with even the closest excavated medieval settlement at Eldbotle (Morrison et al 2008). This may in part be due to the degree of truncation, which has made interpretation of the vestigial remains a challenge. However, the ditches and gullies which appear to delineate structures are unlike anything seen at other contemporary sites and the best parallel identified so far is on Sanday. The 'sunken-floored' structures (F13, F14) are rare in Scottish rural medieval archaeology, the only potential parallel being a working area previously identified at Birnie, Moray (Hunter 2003); although this yielded no datable finds it is likely to have Early Historic or medieval origins. F13 and F14 appear most likely to be the remains of a short-lived workshop, possibly of stone-based turf- or timberwalled construction and associated working area.

The artefact assemblage from this site gives a potential date range from the 12 th to 15 th centuries, although centred on the 13th-14th centuries, and is typical of a rural settlement in the high medieval period when compared with the more abundant examples south of the border. However, comparison with the finds from Springwood and Eldbotle shows it to have less variety. Few imported pottery types were present at Hallhill, despite its coastal proximity, and the range of metal and stone objects was limited. Single objects which might be considered unusual on a rural site are the fragment of painted window glass and the iron arrowhead, although the occasional presence of hunting arrows is known in rural settlements in England and does not need to imply high status or elite connections. Bone preservation at Springwood was poor, but Hallhill is similar to Eldbotle in producing a relatively large quantity of horse (Henderson 2002), and in view of this the possible spur and horse harness fragments are of interest. Both Hallhill and Eldbotle produced very few fish bones despite their proximity to the sea, and this must be related to the nature of the soil. The mollusc remains have been interpreted as fishing bait, suggesting that the occupants were involved in at least some fishing. However, with almost two miles between Hallhill and the closest part of the coast, fishing is unlikely to have been the main source of either food or income for this settlement.

It seems that most of the usual medieval rural activities were taking place at this site. There is evidence for farming and stock-rearing; exploitation of animals for food, skins, wool and horn; grinding of grain; and possibly hunting. In addition, the inhabitants of this settlement were able to exploit the nearby coastal resources, particularly shellfish and sea coal. Unusually, there is no evidence for smithing activities, so presumably the horses present on this site had to be taken elsewhere for shoeing, and metal objects were obtained from nearby markets such as Dunbar itself.

Although little evidence survives for the structural types present on this site, the amount of stone present suggests that this material was largely used for footings. Like the houses at Springwood, it is probable that the stone footings were simply bases for turf or clay walls. Whether they had cruck-framing or used some other method of roofing cannot be reconstructed from their surviving plans. The smallest building, the possible workshop, seems to have had some form of heating, and the possible structure in enclosure F19 may have had a firepit, but there is no real evidence for other internal structures such as partitions or drains.

With the hindsight offered by future excavations, it might be possible to offer a better interpretation of the features present at Hallhill. For now the best we can offer is that we seem to have the edge of an agricultural field system, the possible remains of turf-walled long houses constructed on shallow levelled platforms, with associated areas of craft or industrial activity and at least one workshop. 


\section{ACKNOWLEDGEMENTS}

The authors express gratitude to Piers Dixon, John Lawson, Biddy Simpson and Richard and Ciara Strachan, all of whom visited the excavation and offered much-appreciated advice and expertise; Jenni Morrison who supplied a copy of Headland Archaeology's report on the Eldbotle excavation; and Phil Harding and Colin Martin who supplied a copy of the Time Team's Roxburgh 2003 evaluation report. The excavations were directed by Stuart Mitchell.
The site illustrations are by Ross White and Leeanne Whitelaw, and the artefact illustrations are by Alan Braby. Earlier drafts of this report were commented upon by Andy Dunwell, Melanie Johnson, Tim Neighbour and Biddy Simpson. While thanks are due to the above, responsibility for the final form and content lies with CFA Archaeology Ltd and the authors. 


\section{REFERENCES}

Ambros, C \& Müller, H-H 1980 Frühgeschichtliche Pferdskelettfunde aus dem Gebiet der Tschechoslowakei. Archäologisches Institut der Slowakischen Akademie der Wissenschaften. Bratislava.

Biddle, M \& Smith, D 1990 'The querns' in M Biddle (ed), Object and Economy in Medieval Winchester, 881-90. Winchester (=Winchester Studies 7ii).

Branch, Gm 1985 'Limpets: their role in littoral and sublittoral community dynamics', in P G Moore \& R Seed (eds) The Ecology of Rocky Coasts. London.

Campbell, A C 1989 Seashores and Shallow Seas of Britain and Europe. London.

Cannell, J 1985 'Douglen (Westerkirk p)', Discovery Excav Scot 1985. CBA Scotland.

Clarke, H \& Carter, A 1977 Excavations in King's Lynn 1963-70. London (=Soc Medieval Archaeol Monogr, 7).

Coull, R J 1996 The Sea Fisheries of Scotland: A Historical Geography. Edinburgh.

Cox, A 1996 'Backland activities in medieval Perth: excavations at Meal Vennel and Scott Street'. Proc Soc Antiq Scot, 126, 733-821.

Curtis, A \& Johnson, M 2005 'Halhill Farm, Dunbar, East Lothian. Archaeological Evaluation'. CFA Report No. 1031

Dixon, P 1998 'A rural medieval settlement in Roxburghshire: excavations at Springwood Park, Kelso 1985-6', Proc Soc Ant Scot, 128, 671-752.

Dixon, P 2002 Puir Labourers and Busy Husbandmen. The Countryside of Lowland Scotland in the Middle Ages. Edinburgh.

Driscoll, S 1997 'A Pictish settlement in NE Fife: Excavations at Easter Kinnear', Tayside Fife Archaeol J, 3 .

Dunwell, A 2007 Cist burials and an Iron Age settlement at Dryburn Bridge, Innerwick, East Lothian. Scott Archaeol Internet Rep 24.

Egan, G \& Pritchard, F 1991 Dress Accessories 1150 1450. London.

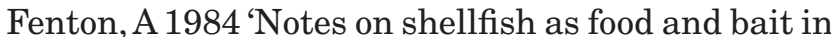
Scotland', in B Gunda (ed) The Fishing Culture of the World. Studies in Ethnology, Cultural Ecology and Folklore, Vol. 1, 121-41. Budapest.

Ford, B A 1987. 'Stone objects', in P Holdsworth, Excavations in the Medieval Burgh of Perth 1979-1981, 147-50. Edinburgh (=Soc Antiq Scot Monogr, 5).

Ford, B 1995 'Artefacts', in D Bowler; A Cox \& C Smith, 'Four excavations in Perth, 1979-84', Proc Soc Antiq Scot, 125, 959-79.

Glendinning, B 2003 Hallhill Farm, Dunbar, East
Lothian. Archaeological Evaluation. CFA Report No. 821.

Glendinning, B 2004 Hallhill Farm, Dunbar, East Lothian. Post-Excavation Costed Assessment. CFA Report No. 890.

Good, G L \& Tabraham, C J 1981 'Excavations at Threave Castle, Galloway 1974-1978', Medieval Archaeol, 25, 90-140.

Goodall, I H 1991 'The ironwork' in P Armstrong; D Tomlinson and DH Evans, Excavations at Lurk Lane, Beverley, 1979-82. Sheffield.

Goodall, I H 1993 'Iron objects', in H K Murray \& J C Murray 'Excavations at Rattray, Aberdeenshire. A Scottish deserted burgh', Medieval Archaeol, $37,175-88$.

Hall, D W 1998 'The Scottish Medieval Pottery Industry - a pilot study' Tayside Fife Archaeol $J$, $4,170-8$.

Hall, D W 2004 'Excavations at the pottery production centre of Colstoun, East Lothian 1939, 1969, 1971, 1977 and 1999/2000', Medieval Ceramics $28,35-74$

Hatherley, C 2009 'Into the west: excavation of an Early Christian cemetery at Montfode, Ardrossan, North Ayrshire', Proc Soc Antiq Scot 139, 195-211.

Hylleberg, J \& Christensen, J T 1977 'Phenotypic variation and fitness of periwinkles (Gastropoda: Littorinidae) in relation to exposure', $J$ Molluscan Studies, 43, 192-9.

Henderson, D 2002 'Assessment of faunal remains', in $\mathrm{J}$ Morrison An Archaeological Excavation of the Medieval Settlement of Eldbotle, Archerfield Estate, Dirleton, East Lothian. Headland Archaeology Ltd.

Hunter, F 2003 'Birnie (Birnie parish), Iron Age and medieval settlement', Discovery Excav Scot, 4, 2003, 96.

Knight, J K 1993 'Excavations at Montgomery Castle Part II The Finds (Metalwork)', Archaeol Cambrensis, 142, 182-242.

Morrison, J; Oram, R \& Oliver, F 2008 'Ancient Eldbotle unearthed: archaeological and historical evidence for a long-lost early medieval East Lothian village', Transactions of the East Lothian Antiquarian and Field Naturalists' Society 28, 21-45.

Morrison, J; Oram, R \& Ross, A 2009 ‘Gogar, archaeological and historical evidence for a lost medieval parish near Edinburgh', Proc Soc Antiq Scot, 139, 229-55.

Oakley, G E and Hall, A D 1971 'Spindle Whorls', in J H Williams, St Peter's Street, Northampton, Excavations 1973-1976, 286-9. Northampton.

Rees, A 2002 'A first millennium AD cemetery, rectan- 
gular Bronze Age structure and late prehistoric settlement at Thornybank, Midlothian', Proc Soc Antiq Scot, 132, 313-56.

Smith, C 1998 'Dogs, cats and horses in the Scottish medieval town', Proc Soc Antiq Scot, 128, $859-85$.

Smith, C 2000 'The animal bone', in D R Perry Castle Park Dunbar. Two Thousand Years on a Fortified Headland, 194-279. Edinburgh (= Soc Antiq Monogr, 16).

Stones, J A 1989 'The small finds: summary report', in J A Stones (ed) Three Scottish Carmelite Friaries: Excavations at Aberdeen, Linlithgow and Perth 1980-1986, 147-65. Edinburgh (= Soc Antiq Scot Monogr, 6).
Wickham-Jones, C 2001 The Landscape of Scotland. A Hidden History. Stroud.

Map sources

Adair, John 1682 East Lothian. NLS Adv.MS.70.2.11 (Adair 10).

Forrest, William 1802 Map of Haddingtonshire. NLS EMS.s.637.

Roy, William 1747-55 Area around Dunbar, in Haddingtonshire. Roy Map 09/4d, SCRAN Ref. 000-000-609-601-R. 